\title{
Reproductive Toxicity Induced By Benzo[a]pyrene Exposure: First Exploration Highlighting The Multi- stage Molecular Mechanism In Female Scallop Chlamys Farreri
}

\section{Ruiyi Xu}

Ocean University of China Fisheries College

Luqing Pan ( $\sim$ panlq@ouc.edu.cn )

Ocean University of China

\section{Yueyao Zhou}

Ocean University of China Fisheries College

\section{Zhongyuan Gao}

Ocean University of China Fisheries College Jingjing Miao

Ocean University of China Fisheries College

Yingying Yang

Ocean University of China Fisheries College

Dongyu Li

Ocean University of China Fisheries College

\section{Research Article}

Keywords: Chlamys farreri, benzo[a]pyrene, endocrine disruption, DNA damage, oogenesis

Posted Date: July 27th, 2021

DOI: https://doi.org/10.21203/rs.3.rs-716571/v1

License: (c) (1) This work is licensed under a Creative Commons Attribution 4.0 International License. Read Full License 


\section{Abstract}

Reproductive toxicity induced by Benzo[a]pyrene (B[a]P) exposure have received great ecotoxicological concerns. However, huge gaps on molecular mechanism still exist in bivalves. In this study, reproductionrelated indicators during reproductive periods (proliferative, growth, mature, and spawn stage) were investigated in female scallops Chlamys farreri, which under gradient concentration of B[a]P at 0, 0.04, 0.4 and $4 \mu \mathrm{g} / \mathrm{L}$. To elucidate the potential molecular mechanisms of reproductive toxicology, a multistage ovarian transcriptome analysis under $4 \mu \mathrm{g} / \mathrm{L}$ B[a]P exposure was also conducted. The results indicated that life-cycle exposure to 0.4 and $4 \mu \mathrm{g} / \mathrm{L} \mathrm{B}[\mathrm{a}] \mathrm{P}$ had significantly decreased GSI and sex steroid levels. Even $0.04 \mu \mathrm{g} / \mathrm{L} \mathrm{B}[\mathrm{a}] \mathrm{P}$ could play the wicked role on DNA integrity at mature and spawn stages. Ovarian histological sections showed the inhibitions on oocyte maturation and ovulation of $\mathrm{B}[\mathrm{a}] \mathrm{P}$ with dose-dependent effects. Through the functional enrichment analysis of DEGs from transcriptome data, 18 genes involved in endocrine disruption effects, DNA damage and repair, and oogenesis damage were selected and further determined by qRT-PCR. The down-regulate of steroidogenic and estrogen signaling pathways genes indicated the endocrine disruption mechanisms by B[a]P, which emphasized the functions of receptor independent and dependent pathways under B[a]P exposure. The variation of DNA single strand break and repair gene expressions implied there might exist the similar toxic mechanism with that in vertebrates. Gene expression data involved in cell cycle, apoptosis and cell adhesion exhibited the possibly toxic mechanisms of oogenesis caused by B[a]P. Taken together, this study is a pioneer to take advantage of genome-wide transcriptomic analysis and its corresponding reproductive indicators to explore the toxic mechanism under B[a]P exposure in bivalves. Meanwhile, some selected genes were firstly identified in bivalves, and the expression data might be useful in establishing new hypotheses and discovering new biomarkers for marine biomonitoring.

\section{Introduction}

With the rapid pace of industrialization and frequent occurrence of marine oil spill accidents, persistent organic pollutants (POPs) are globally detectable in terrestrial and marine environment (Heskett et al. 2012; Wurl and Obbard et al. 2004). Polycyclic aromatic hydrocarbons (PAHs) are one of the most widespread POPs in marine ecosystem, which represent a potential health hazard to aquatic organisms (Ankley et al. 2003; Kim et al. 2013). Due to the carcinogenicity, teratogenicity and mutagenicity of PAHs, sixteen chemicals of them have been classified as the prior controlled contaminants by US Environmental Protection Agency (US EPA) (Office of the Federal Registration, 1982). During the last decades, numerous studies have observed that PAHs pollution could induce adverse effects on reproduction of marine organisms, including sex reversal, delaying gonadal development and spawn probability (Chikae et al. 2004; Rochman et al. 2014; Vignet et al. 2016). For example, reduction in the successful rate of reproduction as well as survival rate of outputs were observed in maternal oyster Crassostrea gigas exposed to a kind of model PAHs, benzo[a]pyrene (B[a]P), during ovarian development (Choy et al. 2007). Consequently, the phenomenon has attracted great concerns due to the strong evidences that PAHs possess high potential to be reproductive toxicants towards marine organisms. 
Currently, plenty of studies suggested an association between PAHs exposure and a range of reproductive toxicity effects in marine organisms, such as endocrine disruption (Collier et al. 2013; Yamamoto et al. 2017), DNA damage (Everaarts and Sarkar 1996; Meier et al. 2020), and histological alterations of gonads (Chukwuka et al. 2019; Louiz et al. 2009). However, information on the underlying toxic mechanisms of PAHs to marine invertebrates, such as mollusks (e.g., bivalves) is relatively scarce (Cuevas et al. 2015; Jing-jing et al. 2009; Sarker et al. 2018; Simão et al. 2020). Traditional studies in bivalves, investigating the toxic mechanism of POPs on reproduction, are based on adverse effects as well as the transcriptional changes of well-known functional genes (Boulais et al. 2018; Yang et al. 2020a; Yang et al. 2020b). Unfortunately, many data gaps still remain in bivalves (Liu et al. 2020). Hence, there is an urgent need for a more efficient method that could comprehensively elucidate the potential molecular mechanism of PAHs exposure on reproduction hazards in mollusks (Honda and Suzuki 2020).

Compared with traditional toxicological data, omics approaches can provide high-throughput data of numerous biomolecules and reflect the integrated global responses within organisms (Chen et al. 2019a; Zhang et al. 2010). Over the past decade, transcriptomic analysis has been well developed and widely introduced in reproductive toxicology studies in many aquatic species, such as fishes (Berg et al. 2016; Colli-Dula et al. 2018; Schiller et al. 2013), crustaceans (Liu et al. 2019; Yu et al. 2018), and bivalves (An et al. 2014; Bachère et al. 2017). Recently, Suman et al. (2020) determined the acute and chronic toxicity of polystyrene microplastics on brine shrimp, and also exhibited the detailed transcriptomic data to enhance current acknowledgement of their molecular toxicity. Overall, the integration of transcriptomic profiling in toxicology and toxicological data can provide a deeper understanding of the mechanism behind toxic processes.

Studies have demonstrated that stage-dependent induction of reproductive toxicity under POPs exposure, especially for early-life stage animals, were the most sensitive groups to given dose (Collier et al. 2013). Additionally, life-cycle POPs exposure has been proved to cause more severe impairment to reproductive functions in fish, such as disturbing steroidogenesis, blocking oocyte development and delaying spawning (Chen et al. 2019b; Horri et al. 2018; Timme-Laragy et al. 2006). However, the majority of previous studies merely conducted as short-term exposure experiments in bivalves, and focused on the specific reproductive stages (mainly at mature stage) during gonadal development (Alonso et al., 2019; Smolarz et al., 2017). The limited research has restricted our comprehensive knowledge on the reproduction-toxic effects of PAHs in bivalves.

Scallop Chlamys farreri is a typical bivalve for coastal monitoring programs, which is frequently used for toxicological studies (Zhang et al. 2011). In the present study, female $C$. farreri were dosed with different concentrations of $B[a] P(0,0.04,0.4$ and $4 \mu \mathrm{g} / \mathrm{L})$ during ovarian development stages (proliferative, growth, mature, and spawn stage), respectively. Where $4 \mu \mathrm{g} / \mathrm{L} \mathrm{B}[\mathrm{a}] \mathrm{P}$ exposure group and control group were conducted for ovarian transcriptome to screen reproductive-toxicology genes for following analysis. Overall, this study first highlighted the multi-stage molecular toxic mechanism by combining transcriptomic analysis and reproductive toxic indicators in bivalves. This would not only promote our 
understanding of the molecular toxicity of $\mathrm{B}[\mathrm{a}] \mathrm{P}$ in bivalves, but also provide vital data for future relevant ecotoxicological studies.

\section{Materials And Methods \\ 2.1 B[a]P preparation}

Benzo[a]pyrene (B[a]P, purity 99\%) was purchased from Sigma Chemical Co. (St. Louis, MO, USA) and dissolved in Dimethyl sulfoxide (DMSO) (Sigma, USA) for concentrated stock solution (with the final DMSO concentration not exceeding $0.001 \%$ ). The three test concentrations of $\mathrm{B}[\mathrm{a}] \mathrm{P}$ at $0.04,0.4$, and 4 $\mu \mathrm{g} / \mathrm{L}$, consistent with the exposure concentrations used for scallops were prepared with DMSO as well. The exposure concentrations were confirmed according to the concentration of $\mathrm{B}[\mathrm{a}] \mathrm{P}$ in the coastal seawater and surface sediments in China and abroad (Sarria-Villa et al. 2016; Wang et al. 2016; Zhang et al. 2016).

\subsection{Scallop treatment and collection}

The experiment was conducted in strict accordance with the national and institutional guidelines for protection of animal welfare, and this study was approved by the Committee on the Ethics of Animal Experiments at Ocean University of China. Female scallops ( $C$. farreri), mainly at pre-proliferative stage, were obtained from Nanshan aquatic market in Qingdao, China. Scallops were placed in 60-L aquaria with $40-\mathrm{L}$ sand-filtered seawater ( $1 \mathrm{~L}$ water per scallop) which containing aerated continuously (renewed completely once a day), at $15 \pm 1^{\circ} \mathrm{C}$ with a light 14 -h dark/10-h light cycle. Scallops were mainly fed with dried powder of Spirulina platensis, and the temperature, salinity, $\mathrm{pH}$ and dissolved oxygen were monitored every day during the acclimatization period.

After one week's acclimatization, scallops were exposed to three concentration gradient of B[a]P at 0.04 , 0.4 , and $4 \mu \mathrm{g} / \mathrm{L}$ (regarded as low, medium, and high-dose group, respectively), and a B[a]P-free solution group was set as the control group. Each group set three replicates. Meanwhile, the B[a]P-free and $4 \mu \mathrm{g} / \mathrm{L}$ $\mathrm{B}[\mathrm{a}] \mathrm{P}$ treatment groups were collected for transcriptome analysis. Based on the ovarian histology by Chung (2008) of $C$. farreri, ovarian samples at four reproductive stages during 29 days exposed experiment were continuously obtained: proliferative stage ( $7 d$, named Pro.); growth stage (14d, named Gro.); mature stage (28d, named Mat.); and spawn stage (29d, named Spa.). The culture managements were the same as the acclimatized period during the whole exposure experiment.

\subsection{Reproduction-related indicators analysis}

\subsubsection{Gonadosomatic index (GSI) determination}

The wet weight of the whole soft tissue and ovaries, of the control and three B[a]P experimental groups, were registered for GSI determination. The GSI was calculated as the formula of GSI= [wet weight of ovary (g) / wet weight of soft tissue (g)]*100 (Frantzen et al. 2016). 


\subsubsection{Steroid hormones extraction and assays}

The three steroid hormones of $P, T, E_{2}$ levels in ovaries were analyzed with the commercial enzyme-linked immunosorbent assays kits (Lengton Biological Technology Co. LTD, China) after steroids extraction. Ovaries samples $(0.1 \mathrm{~g})$ were homogenized in PBS $(\mathrm{pH}=7.4)$ on ice for $10 \mathrm{~min}$, then centrifuged at $3000 \mathrm{rpm}$ for $20 \mathrm{~min}$ at $4^{\circ} \mathrm{C}$, finally the supernatants were collected carefully for further measurement. Concentrations of $P, T$ and $E_{2}$ were measured by use of ELISA kit following the manufacturer's instructions, then quantified with a MULTISKAN GO (Thermo Scientific) at 450nm.

\subsubsection{DNA alkaline unwinding assay}

Under the pre-defined alkaline denaturing conditions, the conversion rate of double stranded DNA (dsDNA) to single stranded DNA (ssDNA) was proportional to the number of breaks in the phosphodiester backbone (Daniel et al., 1985), which was employed as an indicator of DNA integrity.

The methods in this study were performed adapted from Ching et al. (2001) for DNA extraction and alkaline unwinding assay. Briefly, three equal portions for fluorescence determination of dsDNA, sSDNA and alkaline unwound DNA (auDNA) were diluted form DNA samples, and the ratio between dsDNA and total DNA ( $F$ value) was determined using the following formula: $F$ value $=($ auDNA $-s s D N A) /($ dsDNA ssDNA).

\subsubsection{Ovarian histological evaluation}

Ovaries were excised and fixed in with Bouin's solution. After $18 \mathrm{~h}$ of fixation samples were dehydrated through a series of alcohol and xylene and then embedded in paraffin (m.p. $\left.56-58^{\circ} \mathrm{C}\right)$. Sections $(4 \mu \mathrm{m})$ of ovary were cut and stained by Ehrlich's haematoxylin and eosin (H\&E). Then the ovarian sections were observed and photographed by using the Nikon microscope (Nikon, Japan) to determine the reproductive stages and analyze the structure damages caused by B[a]P.

\subsection{Reproduction-toxicology genes exploration by RNA-Seq analysis}

Ovarian samples of $C$. farreri from the control and high-dose B[a]P exposure of $4 \mu \mathrm{g} / \mathrm{L}$, at the Pro., Gro., Mat. and Spa., were used for high-throughput RNA-seq, respectively. The RNA extraction, library construction and RNA-Seq were performed as we described previously (Xu et al., 2020).

In the present transcriptome analysis, genes with the threshold of $p$-value $<0.05$ and |log2(FoldChange) $\geq 1$ between control and its corresponding exposure group at each stage were identified as differentially expressed genes (DEGs). The DEGs were carried out into Gene Ontology (GO) and Kyoto Encyclopedia of Genes and Genomes (KEGG) pathways functional enrichment analysis, consequently, key genes which related to reproductive toxicology were selected for following analysis.

\subsection{Gene expression verification}


Total RNA for qRT-PCR was extracted using reagent RNAiso Plus (TaKaRa Corp., Dalian, China) with genomic DNA removed by RNAse-free DNase. Reverse transcription of each RNA sample was performed to get the first-strand cDNA using Prime Script Reverse Transcriptase kit (TaKaRa, Dalian, China). Then qRT-PCR analysis was used the SYBR Premix Ex TaqTM kit (TaKaRa, Dalian, China) on a PikoREAL96 RealTime PCR System (Thermo Scientific., USA). The thermal profile for SYBR Green RT-PCR was $95^{\circ} \mathrm{C}$ for $30 \mathrm{~s}$, followed by 40 cycles of $95^{\circ} \mathrm{C}$ for $10 \mathrm{~s}$, then $51-55^{\circ} \mathrm{C}$ for $30 \mathrm{~s}, 72^{\circ} \mathrm{C}$ for $30 \mathrm{~s}, 65^{\circ} \mathrm{C}$ to $95^{\circ} \mathrm{C}$ in increments of $0.5^{\circ} \mathrm{C}$ for $5 \mathrm{~s}$.

Gene-specific primers were designed according to Illumina sequencing data with Primer Premier 5. The primer sequences were listed in Table 1. Relative quantification of each target genes was determined using $\beta$-actin gene as the internal reference gene for $C$. farreri ovary (Deng et al. 2016). Then the expression levels of the target genes were calculated with the relative $\mathrm{Ct}$ method (Schmittgen and Livak 2008). Additionally, TBtools software was used to draw the heatmap of genes expression (Chen et al. 2020). And the relationship between RNA-Seq and qRT-PCR was calculated by R ggplot2 package

\subsection{Statistical analysis}

The results were presented as mean \pm standard deviation (SD). SPSS (version 25.0; SPSS, Chicago, IL, USA) software was used for statistical analysis. The data were tested for normality (Shapiro-Wilk) and homogeneity of variance (Levene's), and the statistical differences between the three B[a]P exposure groups with their corresponding control group were evaluated by Dunnett's post-hoc test of one-way analyses of variance (One-way ANOVA) $\left({ }^{*}, p\right.$-value $<0.05 ; * *, p$-value $\left.<0.01\right)$.

\section{Results}

\subsection{B[a]P exposure induced reproduction-related indicators changes}

\subsubsection{Effects of B[a]P exposure on GSI}

The GSI of female $C$. farreri was significantly depressed at $4 \mu \mathrm{g} / \mathrm{L} \mathrm{B}[\mathrm{a}] \mathrm{P}$ exposure groups except at proliferative stage. In addition, GSI at $0.4 \mu \mathrm{g} / \mathrm{L}$ B[a]P exposure was significantly decreased in growth and mature stage. However, there was no difference found in low-dose B[a]P group, compared to the control group during the ovarian development process. It was noteworthy that the $4 \mu \mathrm{g} / \mathrm{L} \mathrm{B}[\mathrm{a}] \mathrm{P}$ treatment had significantly higher GSI at spawn stage than the control group (Fig. 1A).

\subsubsection{Effects of $B[a] P$ exposure on sex steroids levels}

Figure 1B showed the effects of $B[a] P$ exposure on $\mathrm{P}, \mathrm{T}$ and $\mathrm{E} 2$ levels in ovary. The trends of the three sex steroids variation were similar throughout the whole experiment, that all of them continued to increase during gonadal maturation but decreased when reaching spawn stage. The 0.4 , and $4 \mu \mathrm{g} / \mathrm{L} \mathrm{B}[\mathrm{a}] \mathrm{P}$ significantly reduced $\mathrm{P}, \mathrm{T}$ and E2 levels at growth, mature and spawn stages. However, $0.04 \mu \mathrm{g} / \mathrm{L} \mathrm{B}[\mathrm{a}] \mathrm{P}$ 
only significantly inhibited $\mathrm{P}$ concentrations at mature stage and $\mathrm{T}$ level at spawn stage, respectively. In addition, no significant differences in E2 levels were observed during the exposure period between control and low-dose B[a]P exposure group. Overall, some obvious dose-effects were found from the interference effects of $\mathrm{B}[\mathrm{a}] \mathrm{P}$ exposure on sex steroids, and the medium and high dose $\mathrm{B}[\mathrm{a}] \mathrm{P}$ had significantly interfered with the synthesis of steroid hormones.

\subsubsection{Effects of B[a]P exposure on DNA damage}

The effects of $\mathrm{B}[\mathrm{a}] \mathrm{P}$ exposure on DNA alkaline unwinding were shown in Fig. 1C. The results reflected that the medium and high dose B[a]P exposure had induced serious DNA alkaline unwinding during the whole experimental periods, and the low-dose B[a]P at $0.04 \mu \mathrm{g} / \mathrm{L}$ treat group had played its wicked role during the latter experiment (at the mature and spawn stages).

\subsubsection{Effects of B[a]P exposure on Histological alterations}

Ovarian histological sections of female scallops in control group displayed normal characteristics of oogenesis during development process. At proliferative stage, the oogonia and previtellogenic oocyte were found in ovary and scattered on the follicular wall (Fig. 2A). Figure 2E showed that both the number and size of oocytes were gradually increasing and filling the follicles, indicating the coming of growth stage. When ovarian follicles were filled with large numbers of mature oocytes, as well as existing some oogonia oocyte, represented that the female gonads were at mature stage (Fig. $2 \mathrm{I}$ ). In this study $C$. farreri developed into the first spawn stage, the ovarian follicles showed obvious cavity with the discharge of mature oocytes, while the immature oocytes and a small number of mature oocytes remained in the follicles (Fig. 2M).

Ovarian development of female scallop had been severely affected by B[a]P exposure, which showed an inhibitory effect on oocyte maturation and ovulation. Disorganization of the follicular structure occurred when exposed to 0.4 and $4 \mu \mathrm{g} / \mathrm{L} \mathrm{B}[\mathrm{a}] \mathrm{P}$ exposure groups at growth stage, and oocyte damage including disrupted the nuclear membrane as well as cell lysis also appeared (Fig. 2F, G, H). Exposure to the three $\mathrm{B}[\mathrm{a}] \mathrm{P}$ treatment group had deformed the shape of mature oocytes with contraction of cell membrane, in addition, cell lysis, cytoplasmic vacuolation and the alterations of nuclear membrane structure indicated the degeneration of oocytes (Fig. 2J, K, L). Consequently, the spawning process was directly affected by $\mathrm{B}[\mathrm{a}] \mathrm{P}$ exposure due to the delayed ovarian development. The interspace among follicles increased furtherly, and some degenerated oocytes were observed in medium and high B[a]P exposure group (Fig. $2 \mathrm{~N}, \mathrm{O}, \mathrm{P})$. What's more, an obvious time-dose effect was found from the pathologies of ovarian.

\subsection{Screening of key reproductive-toxicology genes under $\mathrm{B}[\mathrm{a}] \mathrm{P}$ exposure through ovarian transcriptome analysis}

\subsubsection{Identification of DEGs}

The overview of transcriptome sequencing results was performed before (Xu et al., 2020). In general, the RNA-seq results indicated that the sequence data were of high quality and appropriate for following 
bioinformatic analysis. The Venn diagram of Fig. 3A showed that there were total of 2,986 DEGs generated from the four comparisons in this study. Specifically, 754 genes at proliferative stage, 960 genes at growth stage, 1708 genes at mature stage, and 495 genes at spawn stage were differentially expressed at $4 \mu \mathrm{g} / \mathrm{L} \mathrm{B}[\mathrm{a}] \mathrm{P}$ exposure condition compared with the control groups, respectively.

\subsubsection{Functional annotation and enrichment analysis of DEGs}

Functional classification of the total 2,986 DEGs were performed via GO and KEGG pathway annotation analysis. Figure 3B showed the Top $30 \mathrm{GO}$ terms at the second level of $\mathrm{GO}$ annotation analysis. For molecular function (MF) category, catalytic activity (with 894 DEGs) and binding (with 843 DEGs) terms dominated the most DEGs. In addition, cellular process and metabolic process with 553 DEGs and 388 DEGs, respectively, had the most DEGs in biological process (BP) category. What's more, membrane part with 1,039 DEGs in cellular component (CC) was the most enriched GO term, which indicated the intense toxic effect of membrane under B[a]P exposure.

Figure $3 \mathrm{C}$ revealed the histogram of KEGG annotation results of the total 2,986 DEGs. Based on the first classifications of KEGG, six types of KEGG pathways were annotated, which included "Metabolism" (with 428 DEGs), Genetic Information Processing" (with 65 DEGs), "Environmental Information Processing" (with 245 DEGs), "Cellular Processes" (with 248 DEGs), "Organismal System” (with 521 DEGs), and "Human Diseases" (with 662 DEGs). Overall, "Human Diseases", "Organismal System", and "Metabolism" dominated the Top 3 KEGG classifications with enriched DEG. Additionally, "Signal transduction" in "Environmental Information Processing", and "Cancers: Overview" in "Human Diseases" had the most DEGs. The results of KEGG annotation indicated the destruction of organism homeostasis under $\mathrm{B}[\mathrm{a}] \mathrm{P}$ exposure, and the carcinogenesis of B[a]P had been confirmed in the ovaries of $C$. farreri.

To further elucidate the detailed pathways and genes linked to reproductive toxicity at specific stages caused by B[a]P, the integrated Top 20 KEGG Level 2 classification was shown in bubble diagram (Fig. 4). Figure 4A, Fig. 4B, Fig. 4C, Fig. 4D represented the KEGG enrichment diagrams of DEGs generated form the four reproductive stages of Pro., Gro., Mat., and Spa. under B[a]P exposure, respectively. For "Metabolism" category, it was notable that "Steroid hormone biosynthesis" pathway was enriched at the four comparisons. For "Environmental Information Processing" category, "Cell adhesion molecules (CAMs)" pathway was enriched in the early stage of ovarian development. For "Cellular Processes" category, "Lysosome" pathway was enriched significantly along with numerous DEGs, and "Oocyte meiosis" pathway of cell growth was significantly enriched at spawn stage. Furthermore, signaling pathways that closely related to oogenesis and ovarian development, including "Estrogen signaling pathway", "Thyroid hormone signaling pathway", "Insulin signaling pathway", "GnRH signaling pathway", "Oxytocin signaling pathway", and "PPAR signaling pathway", were prominently enriched under B[a]P exposure. In addition, DEGs involved in "Single strand break repair (SSBR)".

\subsubsection{Screening of Reproduction-toxicology genes under $\mathrm{B}[\mathrm{a}] \mathrm{P}$ exposure}


In this report, we mainly focused on the DEGs which related to the reproductive toxicology genes which related to oogenesis, endocrine disruption effects, and DNA damage induced by B[a]P. According to the above functional enrichment analysis, a total of 16 key DEGs were screened with their transcriptional changes listed in Table 2. These 18 key DEGs were grouped into three parts, involving (1) Endocrine disruption effects, which including receptor-independence pathway as well as receptor-dependence pathway, (2) DNA damage and repair, and (3) Oogenesis damage, which including cell cycle, apoptosis, and cell adhesion.

\subsection{Expression profile of reproductive-toxicology genes under $\mathrm{B}[\mathrm{a}] \mathrm{P}$ exposure}

\subsubsection{Analysis of expression patterns of Endocrine Disruption Effects genes}

\subsubsection{Analysis of expression patterns of steroidogenesis genes: Receptor-independence pathway}

$\mathrm{B}[\mathrm{a}] \mathrm{P}$ exposure interfered the mRNA expressions of steroidogenesis-related genes were determined (Fig. 5A). At proliferative stage, CYP17 was significantly down-regulated at three B[a]P exposure groups compared with the control group, and the differential expression showed the dose effects. While the expressions of $3 \beta-H S D$ and $17 \beta-H S D$ were only significantly responded to high $\mathrm{B}[\mathrm{a}] \mathrm{P}$ exposure group. At growth stage, the mRNA expression of GnRHR showed significant downregulation at three B[a]P exposure groups, which had the dose effect relations with the exposure concentration. However, the expression levels of CYP17 and Foxl2 showed significant downregulations with their control group at 0.4 , and $4 \mu \mathrm{g} / \mathrm{L}$

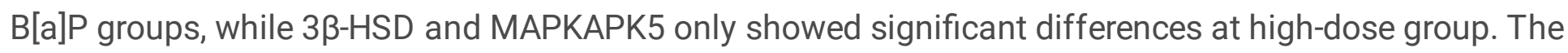
most differential expression of genes occurred at mature stage, the expression levels of CYP17, 3 $\beta-H S D$ and $17 \beta-H S D$ were significantly responded to the three B[a]P exposure groups, while the expressions of GnRHR, MAPKAPK5, and Foxl2 were significantly down-regulated at medium and high dose of B[a]P exposure groups. At spawn stage, except for CYP17 and 17ß-HSD that showed no significant difference with the control groups, the other four genes were all significantly responded to $\mathrm{B}[\mathrm{a}] \mathrm{P}$ exposure. The expression levels of GnRHR, 33-HSD and Foxl2 only showed significant downregulation at $4 \mu \mathrm{g} / \mathrm{L} B[\mathrm{a}] \mathrm{P}$ groups, and MAPKAPK5 mRNA expression was significantly down-regulated at the last two B[a]P groups. Notably, the expression levels of Foxl2 were significantly lower compared with control group among all three $\mathrm{B}[\mathrm{a}] \mathrm{P}$ exposure groups at spawn stage.

\subsubsection{Analysis of expression patterns of Genomic and Non-Genomic Pathways genes: Receptor-dependence pathway}


The effects of $\mathrm{B}[\mathrm{a}] \mathrm{P}$ exposure on mRNA expression of genes responsible for estrogen signaling pathways in female scallop C. farreri were determined (Fig. 5B). Expression of ER and Vtg shared the same pattern: when exposed to high-dose, $4 \mu \mathrm{g} / \mathrm{L} \mathrm{B}[\mathrm{a}] \mathrm{P}$, the expressions were significantly reduced compared to their corresponding controls during the whole experiment period. Additionally, medium dose of $0.4 \mu \mathrm{g} / \mathrm{L} \mathrm{B}[\mathrm{a}] \mathrm{P}$ exposure group significantly down-regulated the expressions of ER at growth and mature stages (Fig. 5B1).

The changes of Cav-1 and Cav-3 mRNA expressions indicated the non-genomic interference effect caused by B[a]P exposure (Fig. 5B2). For high-dose B[a]P exposure group, the variation trend of Cav-1 and Cav-3 mRNA expressions were different at proliferative stage, while they were all up-regulated at growth stage. Cav- 1 was sensitive with $\mathrm{B}[\mathrm{a}] \mathrm{P}$ exposure at spawn stage for its expression showed downregulation trends among the three test concentrations of $\mathrm{B}[\mathrm{a}] \mathrm{P}$. Furthermore, the medium and high dose of $\mathrm{B}[\mathrm{a}] \mathrm{P}$ exposure significantly down-regulated the expressions of Cav-3 at mature and spawn stage.

\subsubsection{Analysis of expression patterns of DNA single strand break repair genes}

Topo1 and XRCC1 were selected to represent the DNA alkaline unwinding and its repairment, respectively (Fig. 5C). The medium and high dose B[a]P treatments significantly down-regulated Topo1 mRNA expression at growth and mature stages. Conversely, the expressions of XRCC1 were significant upregulation at proliferative stage. However, at growth stage, the three $\mathrm{B}[\mathrm{a}] \mathrm{P}$ exposure groups were all significantly regulated the mRNA expression of XRCC1, which indicating the interference of DNA repairment caused by $\mathrm{B}[\mathrm{a}] \mathrm{P}$.

\subsubsection{Analysis of expression patterns of Oogenesis Damage genes}

Figure $5 \mathrm{D}$ shown the effects of $\mathrm{B}[\mathrm{a}] \mathrm{P}$ exposure on the mRNA expressions which related to oogenesis damage. The results indicated that $\mathrm{B}[\mathrm{a}] \mathrm{P}$ had significantly influenced the expression of $\mathrm{CDK} 7$ and $\mathrm{CCNC}$, which related to cell cycle, except at growth stage (Fig. 5D1). Whereas the expressions of FasL and Caspase-8 that involved in apoptosis were upregulated by B[a]P exposure during the latter experiment (at the mature and spawn stages) (Fig. 5D2). For cell adhesion, profilin-2 and COL6A3 mRNA expressions showed cooperatively significant down-regulation under $\mathrm{B}[\mathrm{a}] \mathrm{P}$ exposure during the whole experiment (Fig. 5D3).

\section{Discussions}

The publishment of $C$. farreri genome represents the coming of post-genomic era, while there remains poorly exploration from the genomic perspective (Li et al. 2017; Liu et al. 2020). Additionally, the application of genome-wide transcriptomic analysis in toxicology combined with toxic data, would greatly improve the understanding of the mechanisms underlying toxic processes (Meng et al. 2020; Suman et al. 2020). To our best knowledge, this is the first study to synthetically highlight endocrine 
disrupting effect, DNA single strand break repair, and oogenesis damage induction in bivalves under B[a]P exposure during the whole reproductive period. Importantly, this study is a pioneer to take advantage of transcriptomic analysis and its corresponding toxic data to explore the underlying toxicity mechanism of $\mathrm{B}[\mathrm{a}] \mathrm{P}$ exposed in bivalves. The schematic representation of the possible mechanisms underlying $\mathrm{B}[\mathrm{a}] \mathrm{P}$ induced reproductive toxicology was displayed at Fig. 6 , and the specific functions would be discussed following.

\subsection{Exploration of the toxic mechanism of Endocrine Disrupting Effect under B[a]P exposure}

Strong evidence has indicated that B[a]P could act as an endocrine disrupting chemical (EDC) in aquatic animals, by interfering with the synthesis, secretion and metabolism of steroid hormones (Hoffmann and Oris 2006; Inyang et al. 2003). In this study, KEGG pathway of "steroid biosynthesis" was enriched throughout the four reproductive stages, indicating the endocrine disrupting effect from transcriptome level. In addition, the significant decrease of $\mathrm{P}, \mathrm{T}$ and $\mathrm{E} 2$ directly confirmed the results from the biochemical level. This is consistent with the previous study by Gao et al. (2018), which found that both E2 and T levels were reduced in the ovary of adult female zebrafish under embryonic exposure to B[a]P. Steroid hormones play a crucial role in the regulation of ovarian processes, including controlling follicle growth, oocyte maturation, and spawn (Craig et al. 2011). Thus, the decrease of sex steroid hormones could be a crucial underlying reason for postponed gonadal development in $C$. farreri under B[a]P exposure.

It has been well characterized that steroidogenesis was regulated by the upstream protein kinases (Ras/Raf; MAPK/ERK), Adcy-PKA pathway, and its downstream enzymes (Manna et al. 2009). According to the transcriptome analysis in this study, the collaborative downregulation of steroidogenesis-related genes (upstream: PKA, EGFR, GnRHR, MAPKAPK5; downstream: CYP17, 3 $\beta$-HSD and 17 $\beta$-HSD) probably demonstrated the interference mechanism of $\mathrm{B}[\mathrm{a}] \mathrm{P}$ on steroidogenesis in bivalves (Fig. 6A1). It is noteworthy that $\mathrm{B}[\mathrm{a}] \mathrm{P}$ reduced the expression of Dax 1 during ovarian development, which has been identified to represses the transcriptional activity of steroidogenic factor (SF-1) (Crawford et al. 1998). Deng et al (2010) reported that chronic TBP exposure reduced the transcription of steroidogenic genes (3ß-HSD, 17ß-HSD, CYP17, CYP19A, CYP19B) in the ovary of zebrafish. However, CYP19 has not been sequenced in molluscan genome yet (Scott 2013). Something interesting is that CYP19 has been identified under the temporal and spatial regulation of gene FoxL, and both of them participate in the regulation of sex steroid synthesis (Hudson et al. 2005; Nagahama 2005). Therefore, besides the widely discussed enzymes involved in steroidogenesis, some new genes such as Dax 1 and Fox $L$ should be paid attention when evaluating the B[a]P-induced endocrine disrupting effect (Fig. 6A2).

By mimicking endogenous estrogen, EDCs could bind to ERs and disturb estrogen signaling through genomic and non-genomic pathways. The consistent downregulation of nucleus-ER and Vtg mRNA expression under $4 \mu \mathrm{g} / \mathrm{L}$ B[a]P exposure condition indicated the historically genomic pathway caused by EDCs (Roepke et al. 2005). However, recent evidence indicates that the new non-genomic pathways also 
play crucial roles in estrogen signaling, where EDCs could bind to and activate some non-canonical estrogen receptors, thus leading to rapid stimulation in various protein kinase pathways (Lee et al. 2013; Rosenfeld et al. 2019). Contradictorily, the verified estrogen receptors in non-genomic pathway, such as membrane-ERs and G protein-coupled receptors, have not been sequenced in molluscan genome (Gomesdos-Santos et al. 2020). However, it has been demonstrated that membrane-ERs could be located in caveolae, the invagination of plasma membrane vesicles (Razandi et al. 2002; Stan 2005). Blalock et al. (2018) reported that EDCs could bind to membrane-ERs, then leading to the cell signaling cascade and subsequently impacting on cell cycle in exposed mussels Mytilus edulis. Taken together, the identified non-genomic estrogen signaling pathway related genes (cav-1, cav-2, and CALM) revealed by transcriptomic analysis provided powerful evidence for the further study on B[a]P-induced endocrine disrupting effects in bivalves (Fig. 6B).

\subsection{Exploration of the toxic mechanism of DNA single strand break repair under B[a]P exposure}

DNA damage has been used as the biomarker of POPs exposure in marine bivalve monitoring program (Martins et al. 2013; Mitchelmore and Chipman 1998). It has been shown that exposure to $10 \mu \mathrm{g} / \mathrm{L} \mathrm{B}[\mathrm{a}] \mathrm{P}$ could cause serious DNA single strand break (SSB) in ovary of $C$. farreri (Tian et a. 2014), and the method of DNA alkaline unwinding assay has been widely used to reflect DNA damage effects in bivalves (Slobodskova et al. 2012). In the present study, we observed the significant DNA SSB in all three B[a]P groups during the development process. Banni et al. (2010) reported that B[a]P-induced DNA damage in mussel Mytilus galloprovincialis was positively correlated with the exposure time. When exposed to benzo[k]fluoranthene, the DNA damage in the liver of common carp (Cyprinus carpio) increased with the exposure concentration (Kim et al. 2008). This study further confirmed that DNA damage could be a sensitive biomarker to evaluate marine pollutant stress during the reproductive periods.

DNA damage is a major threat to genetic disorders resulting in cancers while DNA single strand break repair (SSBR) is critical for the survival and genetic stability of mammalian cells (Tubbs and Nussenzweig 2018). However, data on the toxic mechanism of DNA damage effects and repair in bivalves is limited (Li et al. 2020). It has been reported that SSB can be arise either directly (e.g., excessive ROS production) or indirectly (e.g., inactivation of cellular enzymes Topo1) (Whitehouse et al. 2001). Topo1 is important in promoting the formation of DNA circular double stranded molecules (Plo et al. 2003). Srinivasan et al. (2001) reported that PCBs added to human HL-60 cells increased DNA SSB and furtherly found that PCBs inhibited the Topo activity (Srinivasan et al. 2002). The significant decrease of Topo1 expression found in this study implied the potential disturbing mechanism of DNA damage under $\mathrm{B}[\mathrm{a}] \mathrm{P}$ exposure.

The knowledge of DNA repairment in aquatic species is of great importance as it is the primary line of defense against gene-toxicants (Kienzler et al. 2013). SSBR can be divided into four basic steps: (1) DNA damage binding, which was achieved by the ADP-ribose polymerases, such as PARP-1 or PARP-2 (Langelier et al. 2013); (2) DNA end processing, which was stimulated by the interaction with XRCC1 (Ali 
et al. 2009); (3) DNA gap filling with the DNA polymerase Polß (Sugo et al. 2000); and (4) DNA ligation with the involvement of DNA ligase (LIG) (Cappelli et al. 1997). Zuo et al. (2012) found that the expression of both LIG1 and LIG3 were affected in the liver of fish Kryptolebias marmoratus after treatment with tributyltin (TBT). Surprisingly, the SSBR has been poorly investigated in aquatic species despite its key role in repair of oxidative damage (Kienzler et al. 2013). The results in this study suggested there existing the similar toxic mechanism of DNA single strand break and repair under B[a]P exposure in mollusks, while more research should be conducted to verify this hypothesis.

\subsection{Exploration of the toxic mechanism of Oogenesis Damage under $\mathrm{B}[\mathrm{a}] \mathrm{P}$ exposure}

Oocyte is especially susceptible to the adverse effects of environmental toxicants, as well as EDCs (Gregoraszczuk and Ptak A 2013). The retardation of oogenesis and oocytes resorption were observed in the ovary of scallop (Mizuhopecten yessoensis) from heavy organic polluted bay (Vaschenko et al. 1997). Tian et al. (2015) and Yang et al. (2020a) found that B[a]P exposure resulted in a significant decrease in the number of mature sperms and oocytes, respectively. What's more, germ cell apoptotic rate has been used as a reproductive biomarker of contaminant exposure in male fish (Zoarces viviparus) (Lyons et al. 2004). In this study, delayed and abnormal oogenesis was observed during ovarian mature process, with an increasing malignity order depending on dose effect. Additionally, the KEGG functional analysis indicated that "Oocyte meiosis" pathway was significantly enriched at spawn stage under B[a]P exposure. Overall, it could be concluded that B[a]P exposure had seriously affected the normal oogenesis and ovarian functions in $C$. farreri. In this study, genes involved in cell cycle (CDK7 and CCNC), apoptosis (FasL and Caspase-8) and cell adhesion (Profilin-2 and COL6A3) were screened and validated. The variation of oogenesis damage-related gene mRNA expression exhibited the possibly disturbing mechanisms to $\mathrm{B}[\mathrm{a}] \mathrm{P}$, the genes expression data might be useful in discovering new biomarkers to represent reproductive toxicity caused by B[a]P in bivalves (Fig. 6C).

\section{Conclusion}

This study explored the molecular mechanism of reproductive toxicity induced by B[a]P in female scallop $C$. farreri during ovarian developmental process. The changes of reproduction-related indicators including GSI, sex steroid levels, DNA damage and ovarian histology indicated the serious toxic effects caused by $\mathrm{B}[\mathrm{a}] \mathrm{P}$. The expressions data of genes screened by transcriptome analysis elucidated the potential molecular mechanisms of reproductive toxicology under B[a]P exposure. The down-regulate of steroidogenic and estrogen signaling pathways genes emphasized the functions of receptor independent and dependent pathways under B[a]P exposure. The variation of DNA single strand break and repair gene expressions implied there might exist the similar toxic mechanism with that in vertebrates. Gene expression data involved in cell cycle, apoptosis and cell adhesion exhibited the possibly toxic mechanisms of oogenesis caused by B[a]P. In summary, this study promotes the current understanding of molecular toxicity of $\mathrm{B}[\mathrm{a}] \mathrm{P}$ in bivalves, and provides vital data for future relevant ecotoxicological studies. 


\section{Abbreviations}

PKA: cAMP-dependent protein kinase

EGFR: epidermal growth factor receptor

GnRHR: gonadotropin-releasing hormone receptor

MAPKAPK5: MAP kinase-activated protein kinase 5

Dax1: nuclear receptor subfamily 0 group B member 1

CYP17: steroid 17-alpha-hydroxylase/17,20 lyase-like

3ß-HSD: $3 \beta$-hydroxysteroid dehydrogenase

17 $\beta$-HSD: $17 \beta$-hydroxysteroid dehydrogenase

FoxL2: forkhead box protein L2

HSP70: heat shock protein 70

ER: estrogen receptor

Vtg: vitellogenin

Cav-1: caveolin-1

Cav-3: caveolin-3

CALM: Calmodulin

SOD: superoxide dismutase

Topo1: topoisomerase1

PARP1: Poly [ADP-ribose] polymerase 1

XRCC1: X-ray repair cross complementing 1

Polß: DNA polymerase beta

LIG4: DNA ligase 4

CDC25A: M-phase inducer phosphatase

CDK7: cyclin-dependent kinase 7 
CCNC: cyclin C

FasL: tumor necrosis factor ligand superfamily member 6

BIRC2: inhibitor of apoptosis proteins 2

FGFR3: fibroblast growth factor receptor 3

COL6A3: collagen alpha 3 chain

\section{Declarations}

\subsection{Ethics approval and consent to participate}

All experimental procedures were conducted in conformity with institutional guidelines for the care and use of laboratory animals, and protocols were approved by the Institutional Animal Care and Use Committee in Ocean University of China, Qingdao, China.

\subsection{Consent for publication}

Additional informed consent was obtained from all individual participants for whom identifying information is included in this article.

\subsection{Availability of data and materials}

All data generated or analyzed during this study are included in this published article.

\subsection{Competing interests}

The authors declare that they have no conflict of interest.

\subsection{Funding}

This work was supported by the Key Research Project of Shandong (2018) (2018GHY115007).

\subsection{Authors' contributions}

Ruiyi Xu: Conceptualization, Methodology, Investigation, Formal analysis, Resources, Writing - original draft.

Luqing Pan: Conceptualization, Methodology, Resources, Writing - review \& editing.

Yueyao Zhou: Writing - review \& editing, Formal analysis

Zhongyuan Gao: Writing - review \& editing, Investigation

Jingjing Miao: Writing - review \& editing 
Yingying Yang: Writing - review \& editing.

Dongyu Li: Writing - review \& editing.

\section{References}

1. Ali AAE, Jukes RM, Pearl LH et al (2009) Specific recognition of a multiply phosphorylated motif in the DNA repair scaffold XRCC1 by the FHA domain of human PNK. Nucleic Acids Res 37(5):17011712. https://doi.org/10.1093/nar/gkn1086

2. Alonso A, Suarez P, Ruiz Y, Dobal V, San Juan F (2019) Gonadal histopathological disorders in Mytilus galloprovincialis male exposed to tars used in mussel farms. Front Mar Sci 6. https://doi.org/10.3389/fmars.2019.00577

3. Ankley GT, Burkhard LP, Cook PM et al (2003) Photoactivated Toxicity of PAHs to Aquatic Organisms. PAHs: Ecotoxicol Perspect 4:275. https://doi.org/10.1002/0470867132.ch15

4. An L, Zheng B, Liu R et al (2014) Transcriptomic response to estrogen exposure in the male Zhikong scallop, Chlamys farreri. Mar Pollut Bull 89(1-2):59-66.

https://doi.org/10.1016/j.marpolbul.2014.10.035

5. Bachère $E$, Barranger $A$, Bruno R et al (2017) Parental diuron-exposure alters offspring transcriptome and fitness in Pacific oyster Crassostrea gigas. Ecotoxicol Environ Saf 142:51-58. https://doi.org/10.1016/j.ecoenv.2017.03.030

6. Banni M, Negri A, Dagnino A et al (2010) Acute effects of benzo apyrene on digestive gland enzymatic biomarkers and DNA damage on mussel Mytilus galloprovincialis. Ecotoxicol Environ Saf 73:842-848. https://doi.org/10.1016/j.ecoenv.2009.12.032

7. Berg V, Kraugerud M, Nourizadeh-Lillabadi R et al (2016) Endocrine effects of real-life mixtures of persistent organic pollutants (POP) in experimental models and wild fish. J Toxicol Environ Health Part A 79(13-15):538-548. https://doi.org/10.1080/15287394.2016.1171980

8. Blalock BJ, Robinson WE, Loguinov A et al (2018) Transcriptomic and network analyses reveal mechanistic-based biomarkers of endocrine disruption in the marine mussel, Mytilus edulis. Environ Sci Technol 52(16):9419-9430. https://doi.org/10.1021/acs.est.8b01604

9. Boulais M, Vignier J, Loh AN et al (2018) Sublethal effects of oil-contaminated sediment to early life stages of the Eastern oyster, Crassostrea virginica. Environ Pollut 243:743-751. https://doi.org/10.1016/j.envpol.2018.09.017

10. Cappelli E, Taylor R, Cevasco M et al (1997) Involvement of XRCC1 and DNA ligase III gene products in DNA base excision repair. J Biol Chem 272(38):23970-23975. https://doi.org/10.1074/jbc.272.38.23970

11. Chen $\mathrm{C}$, Chen H, Zhang Y et al., 2020. TBtools-an integrative toolkit developed for interactive analyses of big biological data. bioRxiv. 289660. https://doi.org/10.1016/j.molp.2020.06.009

12. Chen L, Lam JCW, Hu C et al (2019a) Perfluorobutanesulfonate exposure skews sex ratio in fish and transgenerationally impairs reproduction. Environ Sci Technol 53(14):8389-8397. 
https://doi.org/10.1021/acs.est.9b01711

13. Chen J, Xu Y, Han Q et al (2019b) Immunosuppression, oxidative stress, and glycometabolism disorder caused by cadmium in common carp (Cyprinus carpio L.): Application of transcriptome analysis in risk assessment of environmental contaminant cadmium. J Hazard Mater 366:386-394. https://doi.org/10.1016/j.jhazmat.2018.12.014

14. Chikae M, Hatano Y, Ikeda R et al (2004) Effects of bis (2-ethylhexyl) phthalate and benzo[a]pyrene on the embryos of Japanese medaka (Oryzias latipes). Environ Toxicol Pharmacol 16(3):141-145. https://doi.org/10.1016/j.etap.2003.11.007

15. Ching EWK, Siu WHL, Lam PKS, Xu LH, Zhang YY, Richardson BJ et al (2001) DNA adduct formation and DNA strand breaks in green-lipped mussels (Perna viridis) exposed to benzo a pyrene: Dose- and time-dependent relationships. Mar Pollut Bull 42:603-610. https://doi.org/10.1016/s0025326x(00)00209-5

16. Choy EJ, Jo Q, Moon H-B, Kang C-K, Kang J-C (2007) Time-course uptake and elimination of benzo (a) pyrene and its damage to reproduction and ensuing reproductive outputs of Pacific oyster, Crassostrea gigas. Mar Biol 151, 157-165. https://doi.org/ 10.1007/s00227-006-0464-4

17. Chukwuka A, Ogbeide O, Uhunamure G (2019) Gonad pathology and intersex severity in pelagic (Tilapia zilli) and benthic (Neochanna diversus and Clarias gariepinus) species from a pesticideimpacted agrarian catchment. south-south Nigeria Chemosphere 225:535-547. https://doi.org/10.1016/j.chemosphere.2019.03.073

18. Chung E-Y (2008) Ultrastructural studies of oogenesis and sexual maturation in female Chlamys (Azumapecten) farreri (Jones \& Preston, 1904) (Pteriomorphia: Pectinidae) on the western coast of Korea. Malacologia. 50: 279-293. https://doi.org/10.4002/0076-2997-50.1.279

19. Colli-Dula RC, Fang X, Moraga-Amador D et al, 2018. Transcriptome analysis reveals novel insights into the response of low-dose benzo (a) pyrene exposure in male tilapia. Aquat. Toxicol. 201: 162173. https://doi.org/10.1016/j.aquatox.2018.06.005Chikae M, Hatano Y, Ikeda R et al., 2004. Effects of bis (2-ethylhexyl) phthalate and benzo [a] pyrene on the embryos of Japanese medaka (Oryzias latipes). Environ. Toxicol. Pharmacol. 16(3): 141-145. https://doi.org/10.1016/j.etap.2003.11.007

20. Collier TK, Anulacion BF, Arkoosh MR et al, 2013. Effects on fish of polycyclic aromatic hydrocarbons (PAHs) and naphthenic acid exposures. Fish Physiol. Academic Press. 33: 195-255.

https://doi.org/10.1016/B978-0-12-398254-4.00004-2Heskett Takada M, Yamashita H R, et al., 2012. Measurement of persistent organic pollutants (POPs) in plastic resin pellets from remote islands: toward establishment of background concentrations for International Pellet Watch. Mar. Pollut. Bull. 64(2): 445-448. http://dx.doi.org/10.1016/j.marpolbul.2011.11.004

21. Crawford PA, Dorn C, Sadovsky Y et al (1998) Nuclear receptor DAX-1 recruits nuclear receptor corepressor N-CoR to steroidogenic factor 1. Mol Cell Biol 18(5):2949-2956.

https://doi.org/10.1128/MCB.18.5.2949

22. Craig ZR, Wang W, Flaws JA (2011) Endocrine-disrupting chemicals in ovarian function: effects on steroidogenesis, metabolism and nuclear receptor signaling. Reproduction 142(5):633. 
https://doi.org/10.1530/rep-11-0136

23. Cuevas N, Zorita I, Costa PM et al (2015) Development of histopathological indices in the digestive gland and gonad of mussels: integration with contamination levels and effects of confounding factors. Aquat Toxicol 162:152-164. https://doi.org/10.1016/j.aquatox.2015.03.011

24. Daniel FB, Haas DL, Pyle SM (1985) Quantitation of chemically induced DNA strand breaks in human cells via an alkaline unwinding assay. Anal Biochem 144(2):390e402. https://doi.org/10.1016/00032697(85)90132-0

25. Deng J, Liu C, Yu L et al (2010) Chronic exposure to environmental levels of tribromophenol impairs zebrafish reproduction. Toxicol Appl Pharmacol 243(1):87-95.

https://doi.org/10.1016/j.taap.2009.11.016

26. Deng X, Pan L, Cai Y et al (2016) Transcriptomic changes in the ovaries of scallop Chlamys farreri exposed to benzo[a]pyrene. Genes Genom 38(6):509-518. http://dx.doi.org/10.1007/s13258-0160397-3

27. Everaarts JM, Sarkar A (1996) DNA damage as a biomarker of marine pollution: strand breaks in seastars (Asterias rubens) from the North Sea. Water Sci Technol 34(7-8):157-162. https://doi.org/10.1016/S0273-1223(96)00739-1

28. Frantzen M, Regoli F, Ambrose WG Jr et al (2016) Biological effects of mechanically and chemically dispersed oil on the Icelandic scallop (Chlamys islandica). Ecotoxicol Environ Saf 127:95-107. https://doi.org/10.1016/j.ecoenv.2016.01.011

29. Gao D, Lin J, Ou K et al (2018) Embryonic exposure to benzo (a) pyrene inhibits reproductive capability in adult female zebrafish and correlation with DNA methylation. Environ Pollut 240:403411. https://doi.org/10.1016/j.envpol.2018.04.139

30. Gregoraszczuk EL, Ptak A (2013) Endocrine-disrupting chemicals: some actions of POPs on female reproduction. Int J Endocrinol. https://doi.org/10.1155/2013/828532

31. Gomes-dos-Santos A, Lopes-Lima M, Castro LF, C et al (2020) Molluscan genomics: the road so far and the way forward. Hydrobiologia 847(7):1705-1726. https://doi.org/10.1007/s10750-019-041111

32. Heskett M, Takada H, Yamashita R et al (2012) Measurement of persistent organic pollutants (POPs) in plastic resin pellets from remote islands: Toward establishment of background concentrations for International Pellet Watch. Mar Pollut Bull 64(2):445-448.

https://doi.org/10.1016/j.marpolbul.2011.11.004

33. Hoffmann JL, Oris JT (2006) Altered gene expression: A mechanism for reproductive toxicity in zebrafish exposed to benzo [a] pyrene. Aquat Toxicol 78(4):332-340. https://doi.org/10.1016/j.aquatox.2006.04.007

34. Honda M, Suzuki N (2020) Toxicities of Polycyclic Aromatic Hydrocarbons for Aquatic Animals. Int J Environ Res Public Health 17(4):1363. https://doi.org/10.3390/ijerph17041363

35. Horri K, Alfonso S, Cousin X et al (2018) Fish life-history traits are affected after chronic dietary exposure to an environmentally realistic marine mixture of PCBs and PBDEs. Sci Total Environ 
610:531-545. https://doi.org/10.1016/j.scitotenv.2017.08.083

36. Hudson QJ, Smith CA, Sinclair AH (2005) Aromatase inhibition reduces expression of FOXL2 in the embryonic chicken ovary. Dev Dyn 233(3):1052-1055. https://doi.org/10.1002/dvdy.20388

37. Inyang F, Ramesh A, Kopsombut P et al (2003) Disruption of testicular steroidogenesis and epididymal function by inhaled benzo (a) pyrene. Reprod Toxicol 17(5):527-537.

https://doi.org/10.1016/S0890-6238(03)00071-6

38. Jing-Jing $M$, Lu-qing $P$, Jing $L$ et al., 2009. Effects of benzo [a] pyrene on DNA damage and histological alterations in gonad of scallop Chlamys farreri. Mar. Environ. Res. 67(1): 47-52. https://doi.org/10.1016/j.marenvres.2008.10.0060ffice of the Federal Registration (OFR), Appendix A: priority pollutants, Fed Reg. 47 (1982) 52309. https://www.law.cornell.edu/cfr/text/40/appendixA_to_part_423

39. Kienzler A, Bony S, Devaux A (2013) DNA repair activity in fish and interest in ecotoxicology: a review. Aquat Toxicol 134:47-56. https://doi.org/10.1016/j.aquatox.2013.03.005

40. Kim KH, Jahan SA, Kabir E et al (2013) A review of airborne polycyclic aromatic hydrocarbons (PAHs) and their human health effects. Environ Int 60:71-80. https://doi.org/10.1016/j.envint.2013.07.019

41. Kim WK, Kim JH, Yeom DH et al (2008) Responses of various biomarkers in Common carp (Cyprinus carpio) exposed to Benzo [k] fluoranthene. Korean J Limnol 41(3):331-337

42. Langelier MF, Pascal JM (2013) PARP-1 mechanism for coupling DNA damage detection to poly (ADP-ribose) synthesis. Curr Opin Struct Biol 23(1):134-143.

https://doi.org/10.1016/j.sbi.2013.01.003

43. Lee HR, Jeung EB, Cho MH et al (2013) Molecular mechanism (s) of endocrine-disrupting chemicals and their potent oestrogenicity in diverse cells and tissues that express oestrogen receptors. J Cell Mol Med 17(1):1-11. https://doi.org/10.1111/j.1582-4934.2012.01649.x

44. Li D, Liu T, Pan L et al (2020) Bioaccumulation and oxidative damage of polycyclic aromatic hydrocarbon mixtures in Manila clam Ruditapes philippinarum. Ecotoxicol Environ Saf 197:110558. https://doi.org/10.1016/j.ecoenv.2020.110558

45. Li YL, Sun XQ, Hu XL et al (2017) Scallop genome reveals molecular adaptations to semi-sessile life and neurotoxins. Nat Commun 8:1721. https://doi.org/10.1038/s41467-017-01927-0

46. Liu M, Pan J, Dong Z et al (2019) Comparative transcriptome reveals the potential modulation mechanisms of estradiol affecting ovarian development of female Portunus trituberculatus. Plos one 14(12):e0226698. https://doi.org/10.1371/journal.pone.0226698

47. Liu F, Li Y, Yu H et al.,2020. MolluscDB: an integrated functional and evolutionary genomics database for the hyper-diverse animal phylum Mollusca. Nucleic Acids Res. 1. https://doi.org/10.1093/nar/gkaa918

48. Louiz I, Ben-Attia M, Ben-Hassine OK (2009) Gonadosomatic index and gonad histopathology of Gobius niger (Gobiidea, Teleost) from Bizerta lagoon (Tunisia): evidence of reproduction disturbance. Fish Res 100(3):266-273. https://doi.org/10.1016/j.fishres.2009.08.009 
49. Lyons BP, Bignell J, Stentiford GD et al (2004) The viviparous blenny (Zoarces viviparus) as a bioindicator of contaminant exposure: application of biomarkers of apoptosis and DNA damage. Mar Environ Res 58(2-5):757-761. https://doi.org/10.1016/j.marenvres.2004.03.091

50. Martins M, Costa PM, Ferreira AM et al (2013) Comparative DNA damage and oxidative effects of carcinogenic and non-carcinogenic sediment-bound PAHs in the gills of a bivalve. Aquat Toxicol 142:85-95. https://doi.org/10.1016/j.aquatox.2013.07.019

51. Manna PR, Dyson MT, Stocco DM (2009) Regulation of the steroidogenic acute regulatory protein gene expression: present and future perspectives. Mol Hum Reprod 15(6):321-333. https://doi.org/10.1093/molehr/gap025

52. Meier S, Karlsen $\varnothing$, Le Goff $J$ et al (2020) DNA damage and health effects in juvenile haddock (Melanogrammus aeglefinus) exposed to PAHs associated with oil-polluted sediment or produced water. PLoS One 15(10):e0240307. https://doi.org/10.1371/journal.pone.0240307

53. Meng Q, Yeung K, Kwok ML et al., 2020. Toxic effects and transcriptome analyses of zebrafish (Danio rerio) larvae exposed to benzophenones. Environ Pollut 114857. https://doi.org/10.1016/j.envpol.2020.114857

54. Mitchelmore CL, Chipman JK (1998) DNA strand breakage in aquatic organisms and the potential value of the comet assay in environmental monitoring. Mutat Res Fundam Mol Mech Mutagen 399(2):135-147. https://doi.org/10.1016/S0027-5107(97)00252-2

55. Nagahama $Y$ (2005) Molecular mechanisms of sex determination and gonadal sex differentiation in fish. Fish Physiol Biochem 31(2-3):105. https://doi.org/10.1007/s10695-006-7590-2

56. Plo I, Liao ZY, Barceló JM et al (2003) Association of XRCC1 and tyrosyl DNA phosphodiesterase (Tdp1) for the repair of topoisomerase I-mediated DNA lesions. DNA repair 2(10):1087-1100. https://doi.org/10.1016/S1568-7864(03)00116-2

57. Razandi M, Oh P, Pedram A et al (2002) ERs associate with and regulate the production of caveolin: implications for signaling and cellular actions. Mol Endocrinol 16(1):100-115. https://doi.org/10.1210/mend.16.1.0757

58. Rochman CM, Kurobe T, Flores I et al (2014) Early warning signs of endocrine disruption in adult fish from the ingestion of polyethylene with and without sorbed chemical pollutants from the marine environment. Sci Total Environ 493:656-661. https://doi.org/10.1016/j.scitotenv.2014.06.051

59. Roepke TA, Snyder MJ, Cherr GN (2005) Estradiol and endocrine disrupting compounds adversely affect development of sea urchin embryos at environmentally relevant concentrations. Aquat Toxicol 71(2):155-173. https://doi.org/10.1016/j.aquatox.2004.11.003

60. Rosenfeld CS, Cooke PS (2019) Endocrine disruption through membrane estrogen receptors and novel pathways leading to rapid toxicological and epigenetic effects. J Steroid Biochem Mol Biol 187:106-117. https://doi.org/10.1016/j.jsbmb.2018.11.007

61. Sarker S, Vashistha D, Sarker MS et al (2018) DNA damage in marine rock oyster (Saccostrea Cucullata) exposed to environmentally available PAHs and heavy metals along the Arabian Sea coast. Ecotoxicol Environ Saf 151:132-143. https://doi.org/10.1016/j.ecoenv.2018.01.004 
62. Sarria-Villa R, Ocampo-Duque W, Páez M et al (2016) Presence of PAHs in water and sediments of the Colombian Cauca River during heavy rain episodes, and implications for risk assessment. Sci Total Environ 540:455-465. https://doi.org/10.1016/j.scitotenv.2015.07.020

63. Schiller V, Wichmann A, Kriehuber R et al., 2013. Transcriptome alterations in zebrafish embryos after exposure to environmental estrogens and anti-androgens can reveal endocrine disruption. Reprod. Toxicol. 2013, 42: 210-223. https://doi.org/10.1016/j.reprotox.2013.09.003

64. Schmittgen TD, Livak KJ (2008) Analyzing real-time PCR data by the comparative $C(T)$ method. Nat Protoc 3(6):1101. https://doi.org/10.1038/nprot.2008.73

65. Scott AP (2013) Do mollusks use vertebrate sex steroids as reproductive hormones? II. Critical review of the evidence that steroids have biological effects. Steroids 78(2):268-281. https://doi.org/10.1016/j.steroids.2012.11.006

66. Simão FCP, Gravato C, Machado AL et al (2020) Effects of pyrene and benzo [a] pyrene on the reproduction and newborn morphology and behavior of the freshwater planarian Girardia tigrina. Chemosphere 264:128448. https://doi.org/10.1016/j.chemosphere.2020.128448

67. Smolarz K, Hallmann A, Zabrzanska S, Pietrasik A (2017) Elevated gonadal atresia as biomarker of endocrine disruptors: field and experimental studies using Mytilus trossulus (L.) and 17-alpha ethinylestradiol (EE2). Mar Pollut Bull 120:58-67. https://doi.org/10.1016/j.marpolbul.2017.04.007

68. Slobodskova VV, Zhukovskaya AF, Chelomin VP (2012) DNA damage in the gill cells of the marine scallop Mizuhopecten yessoensis during anoxic stress and aerobic recovery. Ocean Sci J 47(2):95100. https://doi.org/10.1007/s12601-012-0010-x

69. Srinivasan A, Lehmler HJ, Robertson LW et al (2001) Production of DNA strand breaks in vitro and reactive oxygen species in vitro and in HL-60 cells by PCB metabolites. Toxicol Sci 60(1):92-102. https://doi.org/10.1093/toxsci/60.1.92

70. Srinivasan A, Robertson LW, Ludewig G (2002) Sulfhydryl binding and topoisomerase inhibition by PCB metabolites. Chem Res Toxicol 15(4):497-505. https://doi.org/10.1021/tx010128

71. Stan RV (2005) Structure of caveolae. Biochim Biophys Acta Mol Cell Res 1746(3):334-348. https://doi.org/10.1016/j.bbamcr.2005.08.008

72. Sugo N, Aratani Y, Nagashima $Y$ et al (2000) Neonatal lethality with abnormal neurogenesis in mice deficient in DNA polymerase $\beta$. EMBO J 19(6):1397-1404. https://doi.org/10.1093/emboj/19.6.1397

73. Suman TY, Jia PP, Li WG et al (2020) Acute and chronic effects of polystyrene microplastics on brine shrimp: First evidence highlighting the molecular mechanism through transcriptome analysis. $\mathrm{J}$ Hazard Mater 400:123220. https://doi.org/10.1016/j.jhazmat.2020.123220

74. Tian S, Pan L, Tao Y et al (2015) Environmentally relevant concentrations of benzo [a] pyrene affect steroid levels and affect gonad of male scallop Chlamys farreri. Ecotoxicol Environ Saf 114:150156. https://doi.org/10.1016/j.ecoenv.2015.01.019

75. Tian S, Pan L, Zhang H (2014) Identification of a CYP3A-like gene and CYPs mRNA expression modulation following exposure to benzo [a] pyrene in the bivalve mollusk Chlamys farreri. Mar Environ Res 94:7-15. https://doi.org/10.1016/j.marenvres.2013.11.001 
76. Timme-Laragy AR, Levin ED, Di Giulio RT (2006) Developmental and behavioral effects of embryonic exposure to the polybrominated diphenylether mixture DE-71 in the killifish (Fundulus heteroclitus). Chemosphere 62(7):1097-1104. https://doi.org/10.1016/j.chemosphere.2005.05.037

77. Tubbs A, Nussenzweig A (2018) Endogenous DNA damage as a source of genomic instability in cancer. Cell 168(4):644-656. https://doi.org/10.1016/j.cell.2017.01.002

78. Vaschenko MA, Syasina IG, Zhadan PM et al (1997) Reproductive function state of the scallop Mizuhopecten yessoensis Jay from polluted areas of Peter the Great Bay, Sea of Japan. Asia-Pacific Conference on Science and Management of Coastal Environment. Springer, Dordrecht. 231-240

79. Vignet C, Larcher T, Davail B et al (2016) Fish reproduction is disrupted upon lifelong exposure to environmental PAHs fractions revealing different modes of action. Toxics 4(4):26. https://doi.org/10.3390/toxics4040026

80. Wang Y, Wang JY, Mu JL et al (2016) Aquatic predicted no effect concentrations of 16 PAHs and their ecological risks in surface seawater of Liaodong Bay, China. Environ Toxicol Chem 35(6):15871593. https://doi.org/10.1002/etc.3295

81. Whitehouse CJ, Taylor RM, Thistlethwaite A et al (2001) XRCC1 stimulates human polynucleotide kinase activity at damaged DNA termini and accelerates DNA single-strand break repair. Cell 104(1):107-117. https://doi.org/10.1016/S0092-8674(01)00195-7

82. Wurl O, Obbard JP (2004) A review of pollutants in the sea-surface microlayer (SML): a unique habitat for marine organisms. Mar Pollut Bull 48(11-12):1016-1030. https://doi.org/10.1016/j.marpolbul.2004.03.016

83. Xu R, Pan L, Yang Y et al (2020) Temporal transcriptome analysis in female scallop Chlamys farreri. First molecular insights into the disturbing mechanism on lipid metabolism of reproductive-stage dependence under benzo [a] pyrene exposure. Sci Total Environ 746:142032. https://doi.org/10.1016/j.scitotenv.2020.142032

84. Yamamoto FY, Garcia JRE, Kupsco A et al (2017) Vitellogenin levels and others biomarkers show evidences of endocrine disruption in fish species from Iguaçu River-Southern Brazil. Chemosphere 186:88-99. https://doi.org/10.1016/j.chemosphere.2017.07.111

85. Yang Y, Zhou Y, Pan L et al., 2020a. Benzo [a] pyrene exposure induced reproductive endocrinedisrupting effects via the steroidogenic pathway and estrogen signaling pathway in female scallop Chlamys farreri. Sci Total Environ 138585. https://doi.org/10.1016/j.scitotenv.2020.138585

86. Yang Y, Pan L, Zhou Y et al (2020b) Benzo [a] pyrene exposure disrupts steroidogenesis and impairs spermatogenesis in diverse reproductive stages of male scallop (Chlamys farreri). Environ Res 191:110125. https://doi.org/10.1016/j.envres.2020.110125

87. Yu N, Ding Q, Li E et al (2018) Growth, energy metabolism and transcriptomic responses in Chinese mitten crab (Eriocheir sinensis) to benzo [a] pyrene (BaP) toxicity. Aquat Toxicol 203:150-158. https://doi.org/10.1016/j.aquatox.2018.08.014

88. Zhang A, Zhao S, Wang L et al (2016) Polycyclic aromatic hydrocarbons (PAHs) in seawater and sediments from the northern Liaodong Bay, China. Mar Pollut Bull 113(1-2):592-599. 
https://doi.org/10.1016/j.marpolbul.2016.09.005

89. Zhang W, Li F, Nie L (2010) Integrating multiple 'omics' analysis for microbial biology: application and methodologies. Microbiology 156(2):287-301. https://doi.org/10.1099/mic.0.034793-0

90. Zhang X, Zhao C, Huang C et al (2011) A BAC-based physical map of Zhikong scallop (Chlamys farreri Jones et Preston). PLoS One 6(11):e27612. https://doi.org/10.1371/journal.pone.0027612

91. Zuo Z, Wang C, Wu M et al (2012) Exposure to tributyltin and triphenyltin induces DNA damage and alters nucleotide excision repair gene transcription in Sebastiscus marmoratus liver. Aquat Toxicol 122:106-112. https://doi.org/10.1016/j.aquatox.2012.05.015

\section{Tables}

\section{Table 1}

Primers of the reference gene and target genes in this study for qRT-PCR analysis. 


\begin{tabular}{|c|c|c|c|c|}
\hline & $\beta$ - actin & Forward & СТСССТCACGCTATCCTCCG & 177 \\
\hline & & Reverse & CTGGGCACCTGAACCTTTCG & \\
\hline \multirow[t]{2}{*}{ evm.TU.scaffold55943.2 } & GnRHR & Forward & СТТССТТССССАААТСА & 173 \\
\hline & & Reverse & TCTTCGCCATCAACACT & \\
\hline \multirow[t]{2}{*}{ evm.TU.scaffold36001.45 } & MAPKAPK5 & Forward & ССТСАСТТТАСССССТАС & 142 \\
\hline & & Reverse & GAATAACCСCСАТАСТСC & \\
\hline \multirow[t]{2}{*}{ evm.TU.scaffold43467.35 } & CYP17 & Forward & CGGAAGGTGGAAAGGATA & 188 \\
\hline & & Reverse & GGAGTGGGGAACAAAAGG & \\
\hline \multirow[t]{2}{*}{ evm.TU.scaffold15369.2 } & $3 \beta-H S D$ & Forward & GGAAGGTTAGATGTGGCTGTC & 168 \\
\hline & & Reverse & ACGCTTTGCCATCAACTCT & \\
\hline \multirow[t]{2}{*}{ evm.TU.scaffold60231.7 } & $17 \beta-H S D$ & Forward & CTTGCTGTATTGGTGGGTCTG & 191 \\
\hline & & Reverse & ACCTCTTCCAGCCTCTTTGT & \\
\hline \multirow[t]{2}{*}{ evm.TU.scaffold41309.29 } & FoxL2 & Forward & GGGAAGGTGGAGGTGAAC & 134 \\
\hline & & Reverse & TTTGGGAAGGGATATGGC & \\
\hline \multirow[t]{2}{*}{ evm.TU.scaffold18151.8 } & ER & Forward & CGACAAACGGGAAATCT & 169 \\
\hline & & Reverse & GGCTCGTCATCCACAAC & \\
\hline \multirow[t]{2}{*}{ evm.TU.scaffold25917.13 } & Vtg & Forward & ACCACAAGAACAGAAGCCAATA & 126 \\
\hline & & Reverse & GTAGGTGCCTGGTCTCGTAA & \\
\hline \multirow[t]{2}{*}{ evm.TU.scaffold52871.33 } & Cav-1 & Forward & CGCCCATTTAGGGACTTT & 114 \\
\hline & & Reverse & AGTCCCTTCCAGCATTCG & \\
\hline \multirow[t]{2}{*}{ evm.TU.scaffold27465.18 } & Cav-3 & Forward & CGGAACAACAGCAAGAAGTG & 155 \\
\hline & & Reverse & TCCACAGTTGAAGCAGGAGTAG & \\
\hline \multirow[t]{2}{*}{ evm.TU.scaffold61591.11 } & CDK7 & Forward & AAACCAGGTCTTCACATC & 174 \\
\hline & & Reverse & АСТСАССТТСТАСССТСТ & \\
\hline \multirow[t]{2}{*}{ evm.TU.scaffold19379.7 } & CCNC & Forward & ACCACTGACCGAGTATTT & 100 \\
\hline & & Reverse & GAGGCATACATCTGTTCTTA & \\
\hline
\end{tabular}




\begin{tabular}{ccllc} 
evm.TU.scaffold32013.13 & FasL & Forward & CAGAACTATCCCATAAATCA & 193 \\
\hline evm.TU.scaffold61175.2 & Caspase-8 & Forward & CAAATCGCAGGGTAGTCAC & 145 \\
\hline evm.TU.scaffold63693.7 & Profilin-2 & Forward & TTTACCTAACGGTCTGTG & 145 \\
\hline & & Reverse & ATTGGTGGATACGGGAGA & \\
\hline evm.TU.scaffold36483.74 & COL6A3 & Forward & GGCGTCAGTCCAAATCAT & 184 \\
\hline & & Reverse & GACATCTTGGACGACACT & \\
\hline evm.TU.scaffold39217.1 & Topo1 & Forward & ACGGCACCAGATGTTAC & 175 \\
\hline & & Reverse & ATCCCCCTCCAGTAAGA & \\
\hline evm.TU.scaffold10839.9 & XRCCl & Forward & GGGGAGAAGGAGGACC & 199 \\
\hline & & Reverse & ATGACACTGAAGCGGAG & \\
\hline
\end{tabular}

Table 2 Heatmap showed the list of the selected DEGs which related to the reproductive toxicology induced by $B[a] P$, with their transcriptional changes as well. 


\section{Log2FoldChange}

\section{Reproductive-toxicology effects of $B[a] P$ exposure}

\section{Gene Name}

Con_Pro Con_Gro

_Vs__ _Vs_

_VS_

_VS_

Exp_Pro

Exp_Gro

Exp_Mat

Exp_Spa

\section{Endocrine disruption effects}

\begin{tabular}{|c|c|c|c|c|c|}
\hline \multirow{9}{*}{$\begin{array}{l}\text { Receptor-independence[ } \\
\text { steroidogenesis }\end{array}$} & PKA & up & down & down & down* \\
\hline & EGFR & down & down & down & down* \\
\hline & GnRHR & down & down* & down & down \\
\hline & MAPKAPK5 & up & down & down* & down \\
\hline & Dax1 & up* & up & up & down \\
\hline & CYP17 & down* & down & down & up \\
\hline & $3 \beta-H S D$ & down & up & down* & down \\
\hline & $17 \beta-H S D$ & down & down & down* & up \\
\hline & FOXL2 & up & down & down & down* \\
\hline \multirow{6}{*}{$\begin{array}{l}\text { Receptor-dependence[ } \\
\text { estrogen signaling pathway }\end{array}$} & HSP70 & up & up & down* & up \\
\hline & ER & down & down* & down & down \\
\hline & Vtg & down & down & down & down* \\
\hline & Cav-1 & down & up & up & down* \\
\hline & Cav-3 & up & up* & down* & down \\
\hline & CALM & down & down & down & down* \\
\hline
\end{tabular}

DNA damage

\begin{tabular}{lllllll} 
Single strand break (SSB) & SOD & down & down & down & down* \\
\hline SSB repair (SSBR) & Topo1 & up & down* & down & up \\
& PARP1 & up* & up & down* & up \\
& XRCC1 & up* & down* & up & down \\
& Pol 3 & down & up & down* & down \\
& LIG4 & up & down & down* & up
\end{tabular}

Oogenesis damage 


\begin{tabular}{|c|c|c|c|c|c|}
\hline & CDK7 & down & up & down* & down \\
\hline & CCNC & down* & up & up & up \\
\hline \multirow[t]{3}{*}{ Apoptosis } & FasL & down & down* & down* & up \\
\hline & CASP8 & up & down* & up* & up* \\
\hline & BIRC2 & down & down* & down & down \\
\hline \multirow[t]{3}{*}{ Cell adhesion } & FGFR3 & down & down & down & down* \\
\hline & PFN2 & up & down* & down & down \\
\hline & COL6A3 & down & down & down* & down \\
\hline
\end{tabular}

Figures 
A

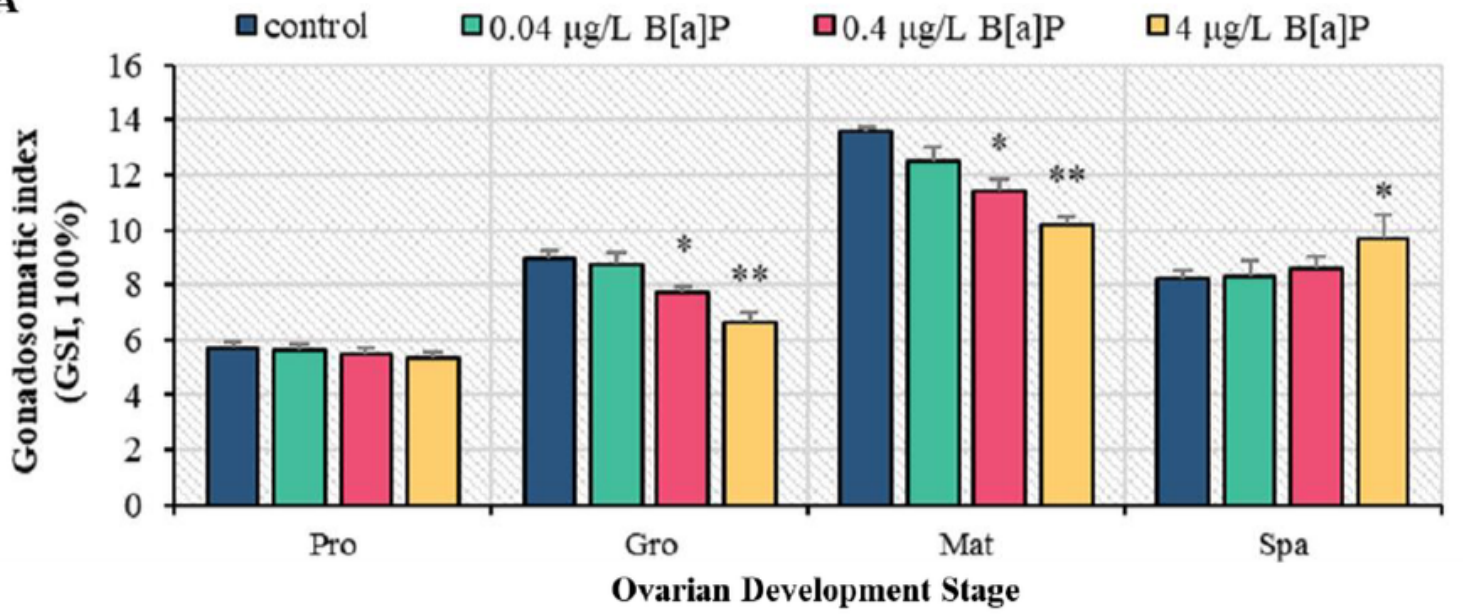

B
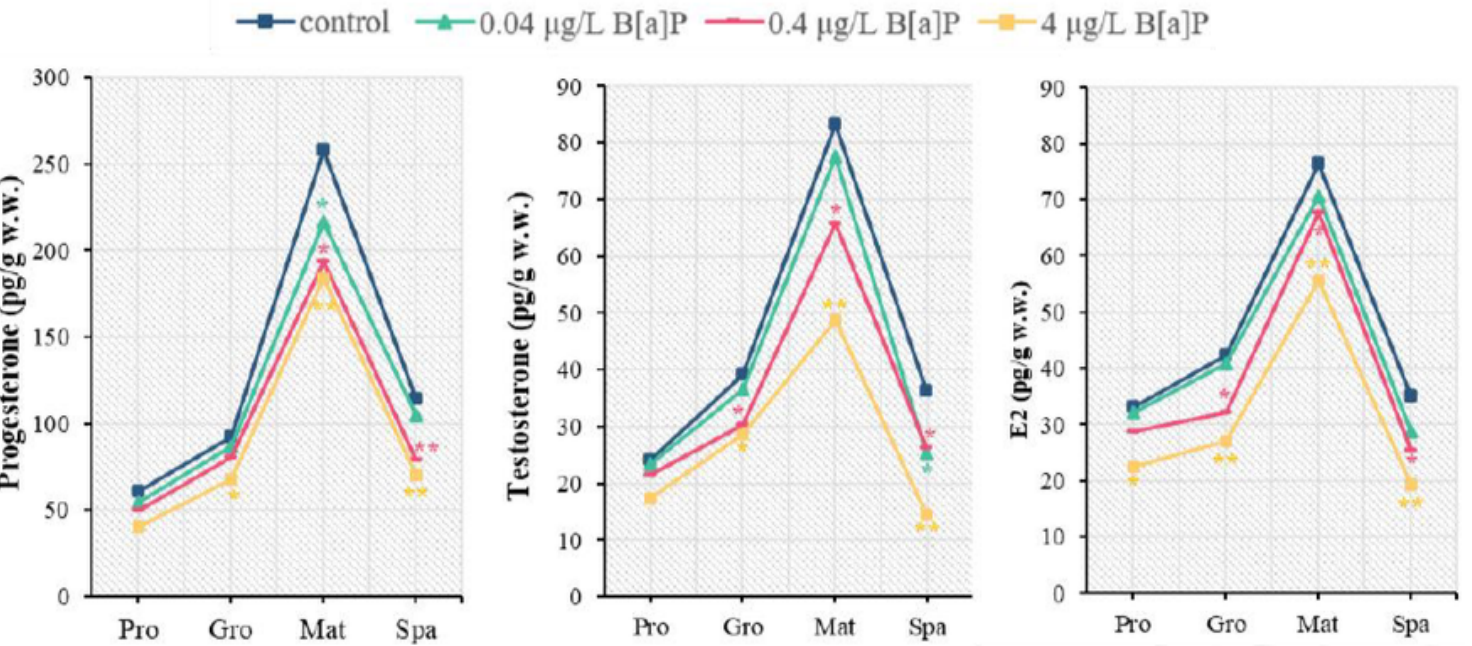

Ovarian Development Stage

C

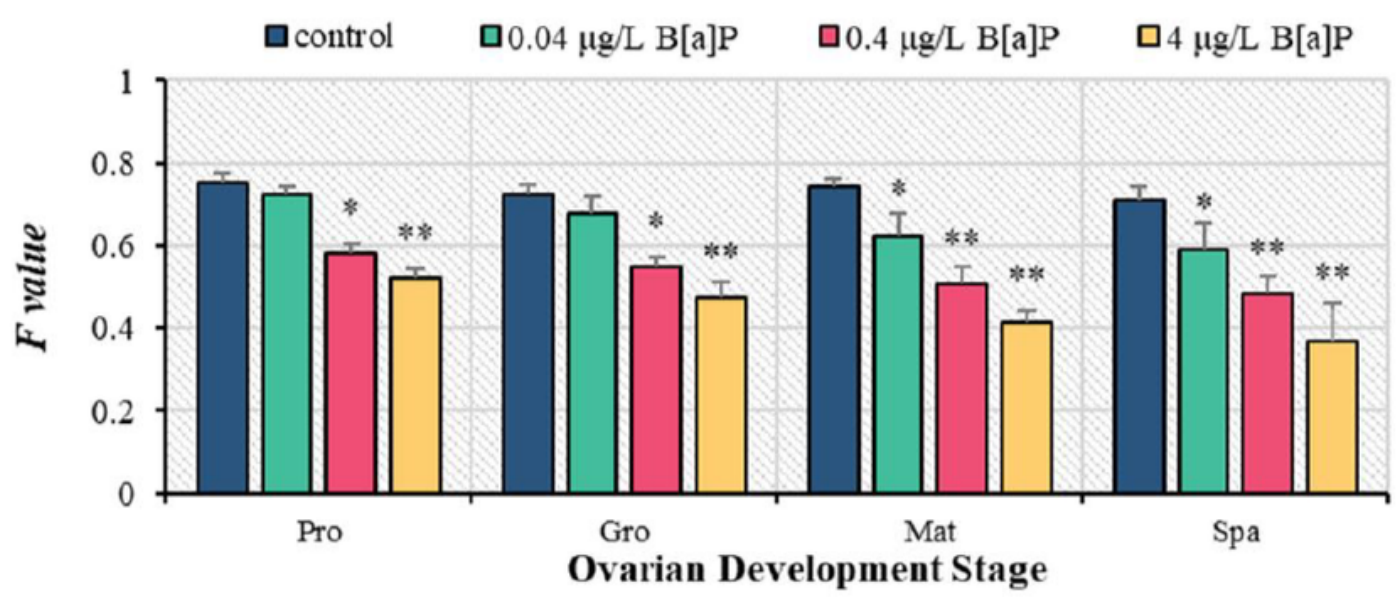

Figure 1

The GSI changes, Endocrine disruption effects, and DNA damage caused by B[a]P exposure in female C. farreri. (A) Effects of B[a]P on the GSI change in female C. farreri during the four ovarian development stages. (B) Effects of $B[a] P$ on sex steroids levels in ovaries of female $C$. farreri during the four ovarian development stages. (C) Effects of B[a]P on DNA alkaline unwinding in ovaries of female C. farreri during the four ovarian development stages. The asterisks indicated statistically significant differences when 
comparing to the corresponding control group (* $p$-value $<0.05$; ${ }^{\star *} p$-value $<0.01$ ). Data are given as mean \pm SD of three replicates.

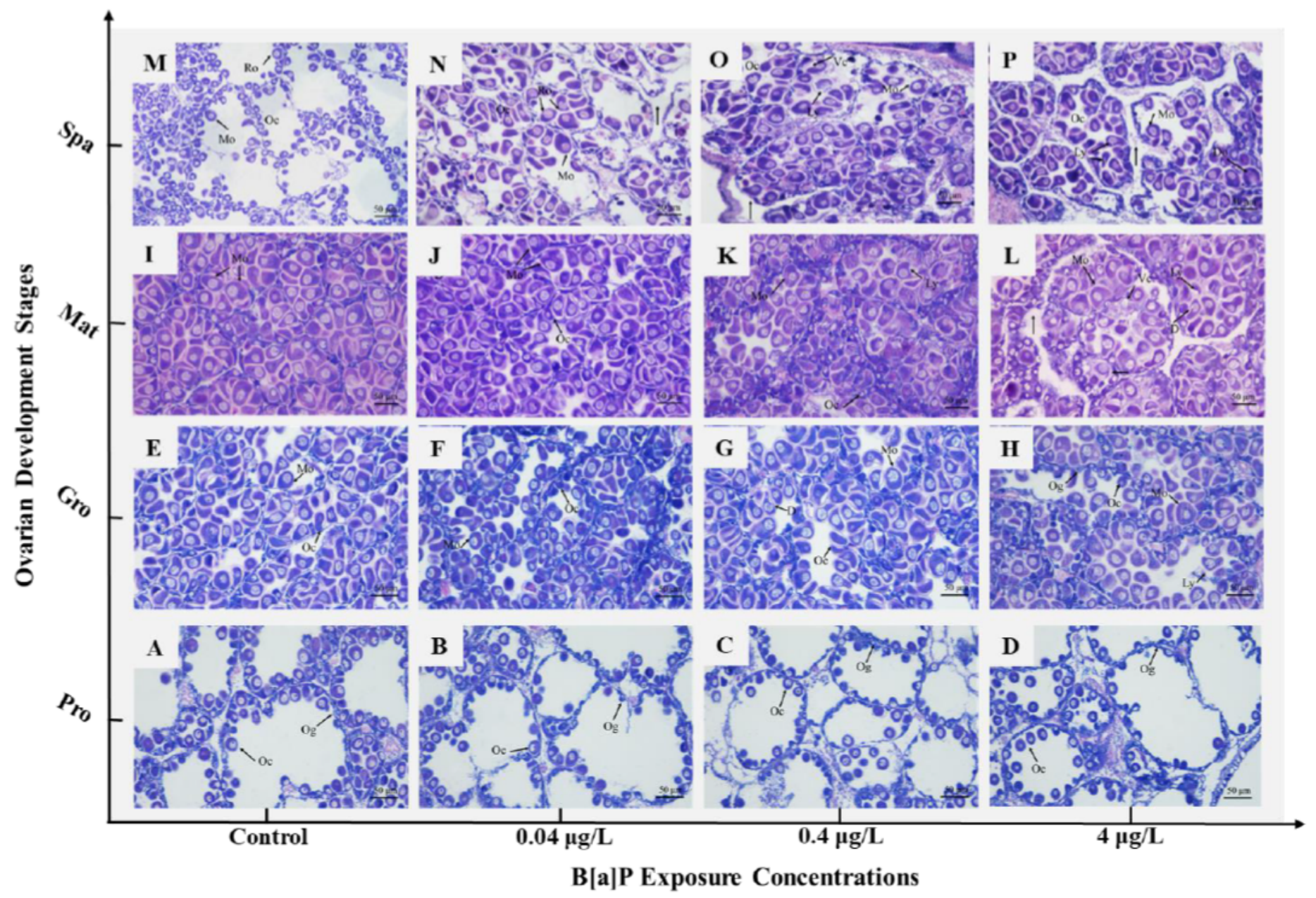

Figure 2

Ovarian histology of $C$. farreri exposed to the control (A, E, I, M), $0.04(B, F, J, N), 0.4(C, G, K, 0)$ and $4(D, H$, $\mathrm{L}, \mathrm{P}) \mu \mathrm{g} / \mathrm{L} \mathrm{B}[\mathrm{a}] \mathrm{P}$ at proliferative stage, growth stage, mature stage, and spawn stage, respectively. Og: oogonia; Oc: oocyte; Mo: mature oocyte; Ro: residual oocyte; Do: degenerating/degenerated oocyte; D: disruption of the nuclear membrane; Ly: cell lysis; VC: vacuolisation of the cytoplasm; $\uparrow:$ interspace among follicles; $\rightarrow$ : sparse cytoplasts of oocytes. 
A

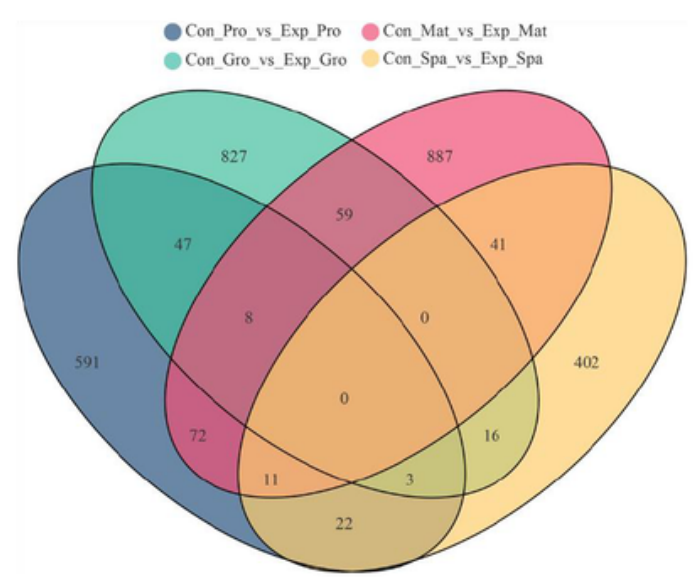

B

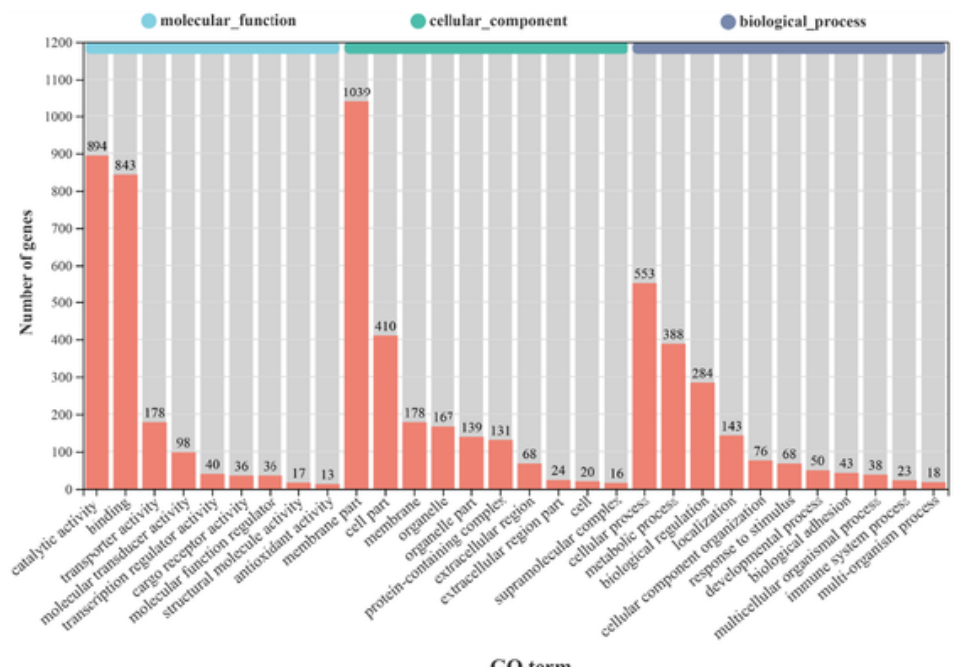

GO term

C

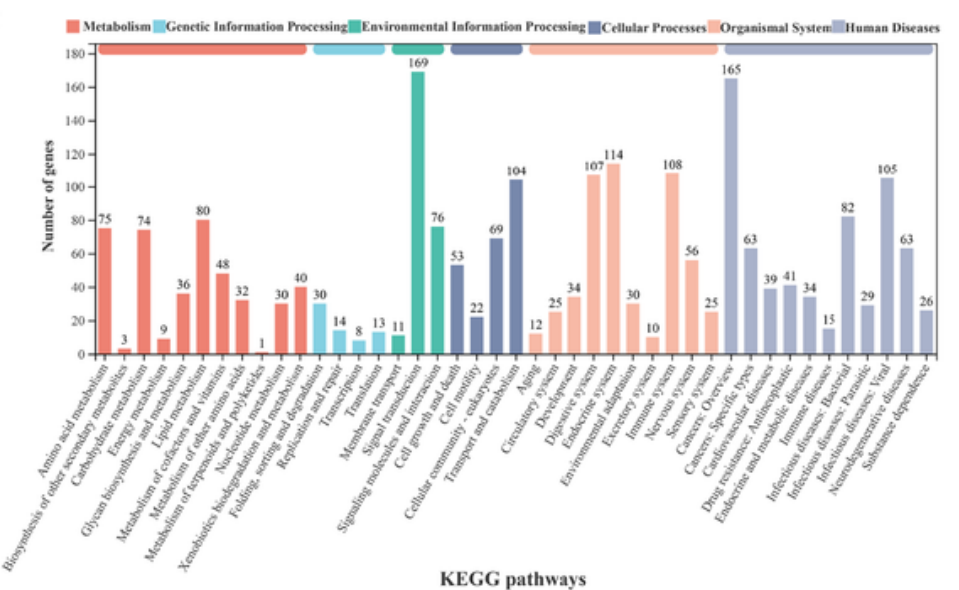

Figure 3

Venn, GO and KEGG pathway enrichment analysis of DEGs. (A) Venn diagram of DEGs among the four comparisons of Con_vs_Exp groups at each reproductive stage; (B) The top $30 \mathrm{GO}$ terms of the total 2,986 DEGs at the second level of GO annotation analysis among molecular function, cellular component, and biological process; (C) The histogram of KEGG annotation of the total 2,986 DEGs among its first classifications, which including "Metabolism”, "Genetic Information Processing”, "Environmental 
Information Processing”, "Cellular Processes", "Organismal System”, and "Human Diseases". Abbreviation: Con, control group; Exp, exposure group; Pro, proliferative stage; Gro, growth stage; Mat, mature stage; and Spa, spawn stage.

A

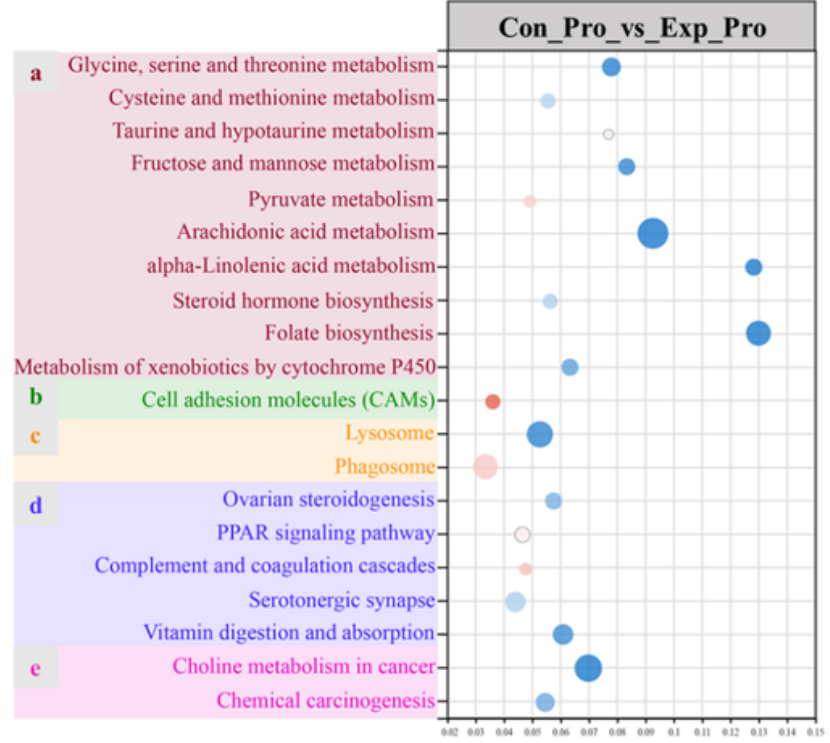

Rich Factor

C

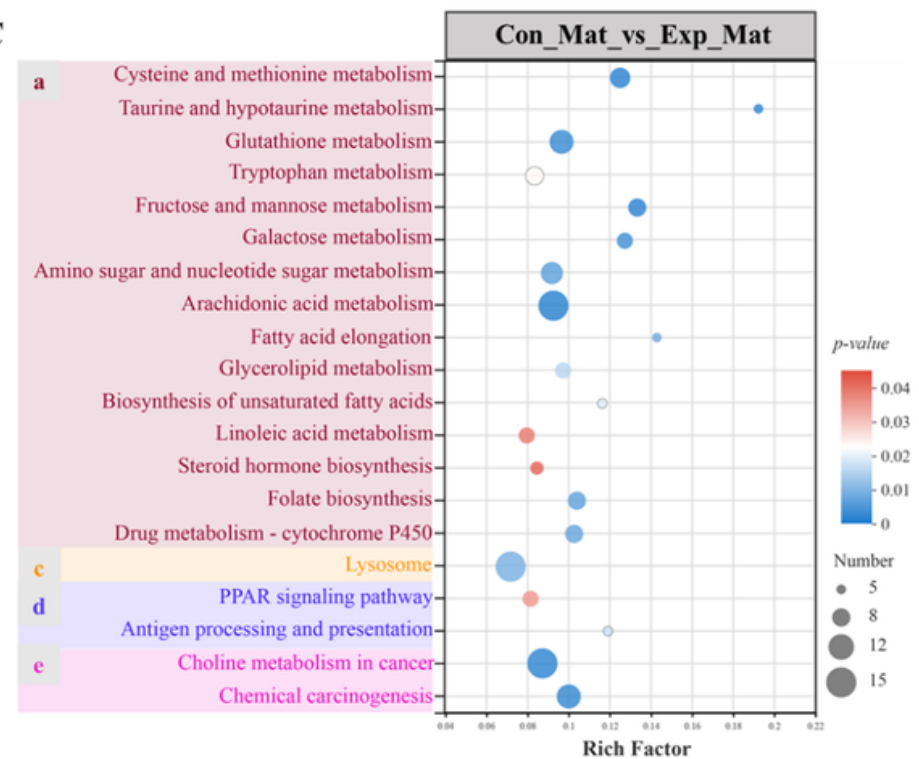

B

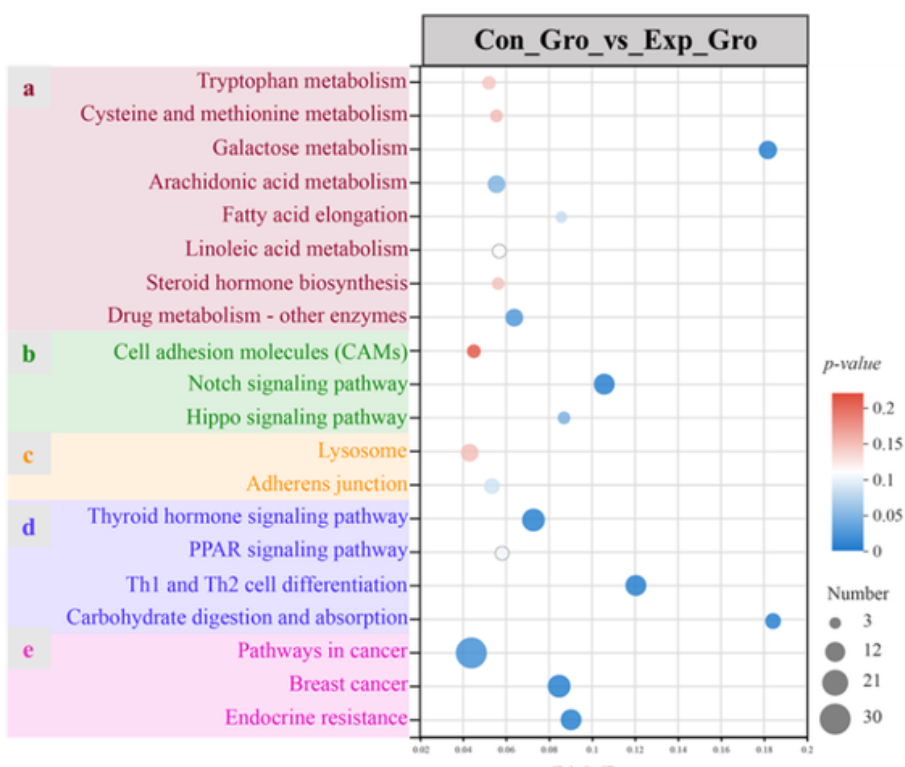

D

Rich Factor

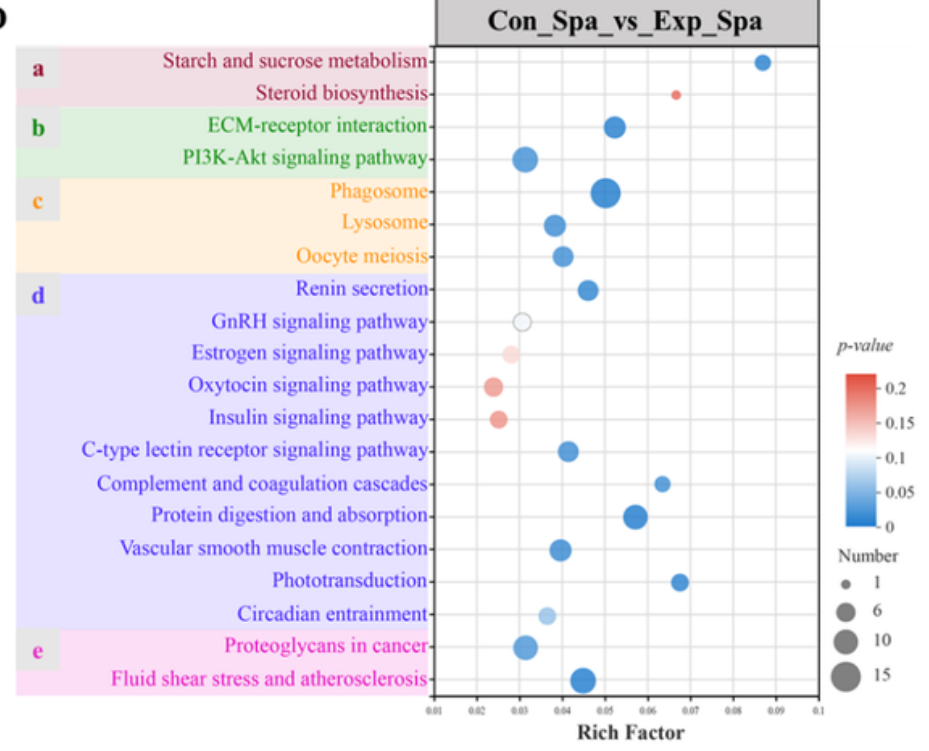

\section{Figure 4}

Top 20 KEGG pathways of Con_Pro_vs_Exp_Pro (A), Con_Gro_vs_Exp_Gro (B), Con_Mat_vs_Exp_Mat (C), and Con_Spa_vs_Exp_Spa (D) DEGs, respectively. KEGG diagram description: on the left of every chart, the red-filled square with red text (a) represented the pathways of "Metabolism"; the green-filled square with green text (b) represented the pathways of "Environmental Information Processing"; the yellow-filled square with yellow text (c) represented the pathways of "Cellular Processes"; the purple-filled square with purple text (d) represented the pathways of "Organismal Systems"; and the purple-filled square with purple text (d) represented the pathways of "Cellular Processes"; the pink-filled square with pink text (e) represented the pathways of "Human Diseases". Additionally, the rectangular at right represented the 
saliency, and the colors from blue to red represent the decrease of saliency with p-value. Larger bubbles indicate a higher number of DEGs.

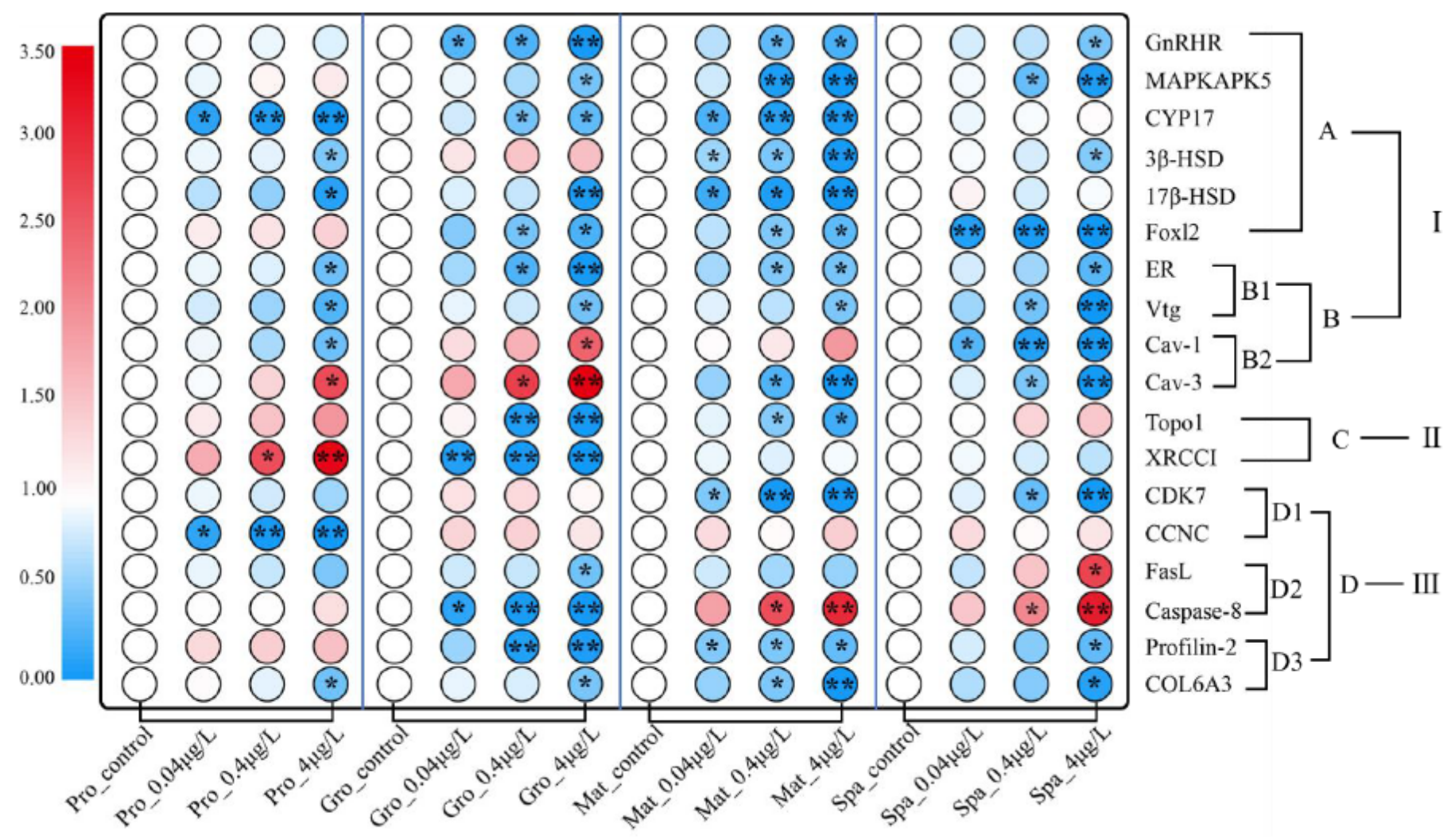

\section{Figure 5}

Heatmap showed the transcriptional levels of genes related to reproductive-toxicology effects caused by $B[a] P$ exposure in female $C$. farreri. I: genes involved in endocrine disruption effects, including steroidogenesis (A) and estrogen signaling pathway (B), further divided into genomic pathway (B1) and non-genomic pathway (B2). II: genes involved in DNA single strand break and repair (C). III: genes involved in oogenesis damage, which including cell cycle (D1), apoptosis (D2), and cell adhesion (D3). The rectangular at left represented the transcriptional levels of genes, while the red indicated the upregulation and the blue indicated the downregulation. The asterisks indicated statistically significant differences when comparing to the corresponding control group ( ${ }^{*} p$-value $<0.05$; ${ }^{* *} p$-value $<0.01$ ). Data are given as mean \pm SD of three replicates. 
A1

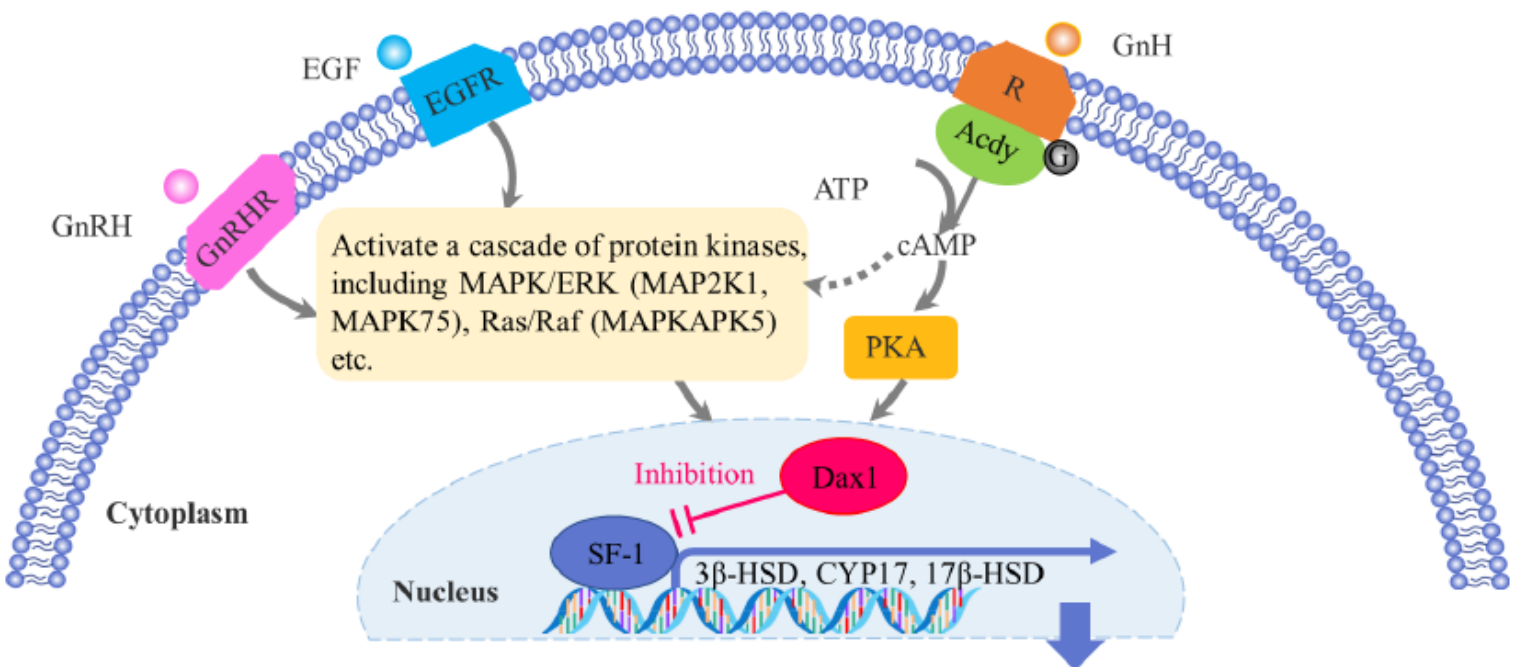

A2
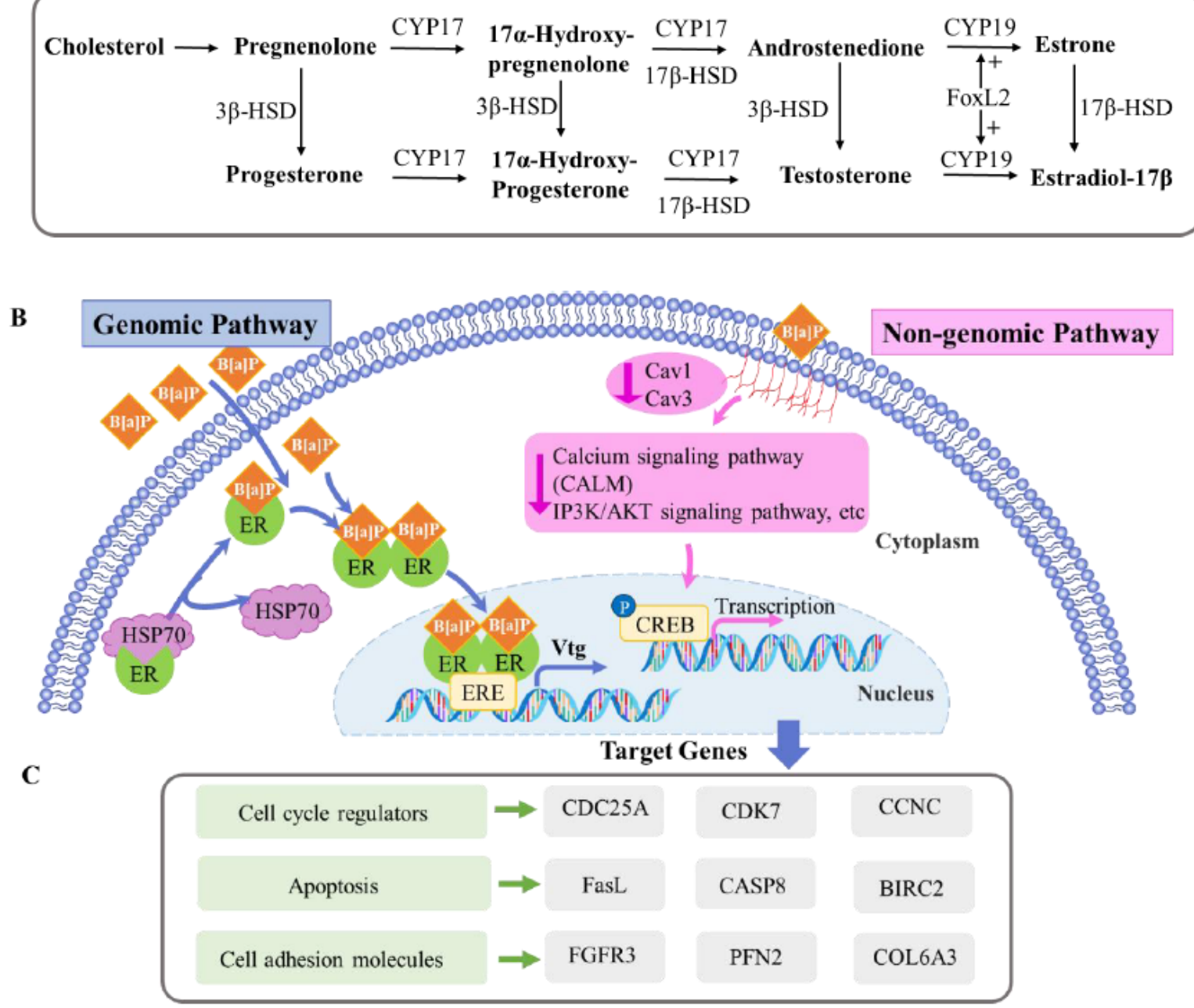

\section{Figure 6}

Possible molecular mechanisms of reproductive toxicology effects caused by B[a]P exposure in C. farreri Schematic model illustrated the signaling pathways for hormone regulation of steroidogenesis (A1) and steroidogenesis-related downstream genes (A2). (B) Schematic model illustrated the effects of B[a]P on estrogen signaling pathway. (C) The downstream genes of estrogen signaling pathway involved in oogenesis damage, which including cell cycle, apoptosis, and cell adhesion. 